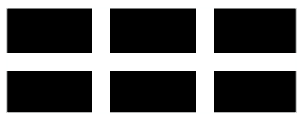

ThE William DAVIDSON INSTITUTE AT THE UNIVERSITY OF MICHIGAN BUSINESS SCHOOL

\title{
Do Insider Trading Laws Matter? Some Preliminary Comparative Evidence
}

\author{
By: Laura Nyantung Beny
}

William Davidson Institute Working Paper Number 741

January 2005 


\title{
DO INSIDER TRADING LAWS MATTER? SOME PRELIMINARY COMPARATIVE EVIDENCE
}

\author{
Laura Nyantung Beny*
}

\section{Forthcoming in American Law and Economics Review Symposium on Comparative Law and Economics (A. Shleifer, ed.)}

\author{
University of Michigan Law School \\ 625 South State Street \\ Ann Arbor, MI 48109 \\ Phone: (734) 647-9054 \\ Fax: (734) 764-8309 \\ lbeny@umich.edu
}

\footnotetext{
* Assistant Professor of Law, University of Michigan Law School. I thank Andrei Shleifer and an anonymous referee for very helpful comments and suggestions on this article. I am also grateful to Lucian Bebchuk, Randy Bezanson, Margaret Brinig, John Coates, Stanislav Dolgopolov, Merritt Fox, Zohar Goshen, Howell Jackson, Myra Kim, Rafael La Porta, Richard Lempert, John Reitz, Daria Roithmayr, William Wang and participants at seminars and workshops at Harvard University, Michigan Law School, Northwestern Law School and the Midwestern Law and Economics Association Annual Meeting 2004. Thanks also to Ron Alquist, Jonathan Ho and Cynthia Kao for research assistance. I am especially grateful to Andrei Shleifer for guidance through the many stages of the larger project and to Peter Henry and Daria Roithmayr for their warm, collegial guidance. I gratefully acknowledge financial support from the John M. Olin Center for Law, Economics and Business at Harvard Law School, the John M. Olin Center for Law and Economics at Michigan Law School, and the Cook Fund of the University of Michigan Law School. I will be forever indebted to Donald J. Brown for illuminating my path. This article is based on an earlier article, “A Comparative Empirical Investigation of Agency and Market Theories of Insider Trading,” John M. Olin Center for Law, Economics and Business Working Paper 264, Harvard Law School, which received the John M. Olin Prize for Outstanding Paper in Law and Economics.
} 


\title{
DO INSIDER TRADING LAWS MATTER? SOME PRELIMINARY COMPARATIVE EVIDENCE
}

(C) 2004 Laura Nyantung Beny. All rights reserved.

\begin{abstract}
Despite the longstanding insider trading debate, there is little empirical research on insider trading laws, especially in a comparative context. The article attempts to fill that gap. I find that countries with more prohibitive insider trading laws have more diffuse equity ownership, more accurate stock prices, and more liquid stock markets. These findings are generally robust to controlling for measures of disclosure and enforceability and suggest that formal insider trading laws (especially their deterrent components) matter to stock market development. The article suggests further avenues of empirical research on the specific mechanisms through which insider trading laws might matter and the political economy of their adoption.
\end{abstract}

Keywords: Insider trading law, Market efficiency, Ownership structure, Law and finance, Comparative capital markets

JEL Codes: K22, G14, G15, G18 and G32. 


\section{INTRODUCTION}

The law and economics debate about insider trading (that is, trading by corporate insiders or their associates on the basis of price-sensitive, private information) is both long-standing and inconclusive. ${ }^{1}$ Scholars on one side of the debate argue that insider trading is efficient and public regulation is inefficient (see, e.g., Carlton and Fischel, 1983; Manne, 1966), while scholars on the other side of the debate argue the opposite (see, e.g., Cox, 1986; Georgakopoulos, 1993; Kraakman, 1991). Although the "desirability of [regulating] insider trading is ultimately an empirical question” (Carlton and Fischel, 1983, p. 866), the insider trading debate thus far has been largely theoretical. It has also implicitly assumed background securities markets and corporate governance institutions like those of the United States and Canada. However, recent studies in comparative corporate and securities law and finance suggest that the implications of these laws vary systematically with economic, legal, institutional and even social differences across countries. The aim of the article is therefore to conduct an exploratory empirical analysis of the relationship between insider trading laws and financial structure and performance across countries.

The article is complementary to Bhattacharya and Daouk (2002). That study addresses the effect of the initial enactment and enforcement of insider trading laws on the cost of equity capital. $^{2}$ Bhattacharya and Daouk (2002) track 51 countries for over more than 20 years; thus, they have a large sample size and high statistical power. However, their insider trading law variables are fairly rudimentary, because they measure only whether an insider trading prohibition exists and whether, if it exists, the prohibition has been enforced once. Nevertheless, such measures are sufficient for their main inquiry, which is the impact of a regime shift from no insider trading prohibition/enforcement to insider trading prohibition/enforcement on the cost of equity. In contrast, my inquiry is whether differences in specific legal elements of countries' insider trading laws are associated with differences in the structure and performance of their stock markets. To address this question, I focus on the aspects of countries' insider trading laws that I believe, a priori, to be substantively meaningful from a legal and economic perspective, ${ }^{3}$

\footnotetext{
1 See Bainbridge (1999) for a thorough summary of the issues in the debate.

2 The major finding of that study is that the cost of equity in a country falls by about $5 \%$ upon the first prosecution of that country's insider trading prohibition, while the enactment of the prohibition has no effect on the cost of equity.

3 Several subsequent studies utilizing the measures of insider trading law developed in this paper confirm the economic significance of these measures (Bris, 2003; Durnev and Nain, 2004; Herrington, 2004).
} 
with an emphasis on deterrence. It is thus appropriate to view Bhattacharya and Daouk (2002) and this article in a complementary light.

Using financial, legal, and institutional data from a cross-section of 33 countries, I find that countries with more prohibitive insider trading laws generally have more dispersed equity ownership, more informative stock prices, and more liquid stock markets. These preliminary findings suggest that formal insider trading laws (especially their deterrent elements) matter to stock market development. The specific mechanisms through which formal insider trading laws might matter and the political economy of their adoption merit further empirical study.

The article is organized as follows. Part II briefly summarizes existing theories of insider trading/regulation and presents three testable hypotheses. In Part III, I describe the data and present univariate statistics. Part IV presents and discusses the regression results. Finally, Part $\mathrm{V}$ concludes and suggests promising avenues for future research.

\section{THEORIES OF INSIDER TRADING AND TESTABLE HYPOTHESES}

\section{A. Insider Trading Regulation and Ownership Concentration}

Regardless of whether insider trading is harmful or beneficial, there are several reasons why insider trading (or lax insider trading laws) might be associated with greater ownership concentration. First, insider trading might create adverse selection problems (Manove, 1989). If outsiders are sophisticated, they will simply discount the price that they are willing to pay for the firm's shares to account for adverse selection from insider trading (Manove, 1989). If outsiders are unsophisticated, however, they might refrain altogether from purchasing shares when insider trading rules are weak or nonexistent, thus hindering dispersed share ownership (Ausubel, 1990). Second, insider trading might exacerbate agency problems within the firm (see, e.g., Bebchuk and Fershtman, 1990; Haft, 1982; Maug, 2002) and therefore discourage outside investment (La Porta et al., 1997, 1998).

Finally, even if insider trading is beneficial, it might still foster concentrated ownership. Large shareholders often play a valuable monitoring role (see, e.g., Bhide, 1993; Demsetz, 1986; Shelifer and Vishny, 1986). However, they must be compensated for that and for the risks associated with holding undiversified portfolios. A potential compensation mechanism is insider trading (Bhide, 1993; Demsetz, 1986). Permitting insider trading might therefore encourage large shareholding by active investors, while legally prohibiting insider trading might have the opposite effect (Bhide, 1993; Demsetz, 1986). For the foregoing reasons, countries seeking to 
promote widespread equity ownership might consider prohibiting insider trading.

\section{B. Insider Trading Regulation and Stock Price Informativeness}

One of the most contentious issues in the insider trading debate is whether insider trading makes stock prices more or less informative (see, e.g., Kraakman, 1991; Manne, 1966). ${ }^{4}$ On the one hand, insider trading might make a stock's price more informative by moving it more quickly to the firm's true value (Carlton and Fischel, 1983; Manne, 1966). ${ }^{5}$ On the other hand, insider trading could pervert corporate insiders' incentives to release information to the market, making stock prices less informative (Benabou and Laroque, 1992; Kraakman, 1991). Another way in which insider trading might make stock prices less informative is by reducing (outside) informed traders' incentives to uncover firm-specific information ${ }^{6}$ by: (1) increasing the risk of expropriation by corporate insiders (Morck, Yeung, and Yu, 2000); and/or by (2) reducing competition in the market for information (Fishman and Hagerty, 1992; Georgakopoulos, 1993; Goshen and Parchomovsky, 2001). ${ }^{7}$

\section{Insider Trading Regulation and Stock Market Liquidity}

A final important issue in the insider trading debate is the effect of insider trading on stock market liquidity (see, e.g., Carlton and Fischel, 1983; Georgeakopoulos, 1993; Goshen and Parchomovsky, 2001; Haddock and Macey, 1986b, 1987). Finance scholars generally agree that information asymmetry can compromise liquidity (see, e.g., Copeland and Galai, 1983; Glosten and Harris, 1988; Leland,1992). ${ }^{8}$ In Copeland and Galai (1983), for example, dealers subsidize their trading losses vis-a-vis informed traders by charging liquidity traders an immediacy fee (the bid-ask spread), which increases in the degree of information asymmetry. ${ }^{9}$ Since insider trading exacerbates information asymmetry, it should raise trading costs (Fishman and Hagerty, 1992; Georgakopolous, 1993; Shin, 1996). In turn, greater trading costs imply lower stock market

\footnotetext{
4 This is an important issue because more informative stock prices lead to a more efficient allocation of capital in the economy (Wurgler, 2000).

5 Manne (1966) and Carlton and Fischel (1983) argue that insider trading is less expensive than traditional means of information disclosure.

6 The collective trading of informed traders leads to more efficient capitalization of firm-specific information into stock prices (see, e.g., French and Roll, 1986; Goshen and Parchomovsky, 2001; Grossman, 1976; Morck, Yeung, and Yu, 2000; Roll, 1988; Shleifer and Vishny, 1997).

7 Consistent with this, Bushman, Piotroski and Smith (2004) find that analyst following increases after countries' initial enforcement of insider trading laws.

8 This work builds on Akerlof's (1970) original insight that markets malfunction in the presence of asymmetric information and, in extreme cases, may break down entirely.

9 Stoll (1989) finds that $43 \%$ of the bid-ask spread of NASDAQ/National Market System stocks is due to adverse information costs.
} 
liquidity.

\section{Testable Hypotheses}

The preceding discussion suggests the following testable hypotheses:

Hypothesis 1 ("H1"): More prohibitive insider trading laws are associated with greater ownership dispersion.

Hypothesis 2 (“H2"): More prohibitive insider trading laws are associated with more informative stock prices.

Hypothesis 3 (“H3”): More prohibitive insider trading laws are associated with greater stock market liquidity.

\section{THE VARIABLES AND UNIVRIATE STATISTICS}

The initial sample consists of a cross-section of 33 countries. The countries vary along several important dimensions, including the efficiency, transparency and regulation of their stock markets, their corporate laws and corporate governance structures, their legal traditions, and the quality of their law enforcement and other institutions.

\section{A. The Variables}

\section{The Dependent Variables}

Hypotheses 1-3 require measures of ownership dispersion, stock price informativeness, and stock market liquidity. These data come from several sources. First, ownership data come from La Porta et al. (1998). They define ownership concentration as the average ownership concentration of the three largest shareholders in the ten largest private non-financial firms in the economy. I define ownership dispersion as one minus La Porta et al.'s (1998) ownership concentration measure. Thus defined, ownership dispersion is the average fraction of shares owned by all shareholders except the three largest shareholders in the ten largest private nonfinancial firms in the economy.

Second, Morck, Yeung, and Yu's (2000) measure of stock price synchronicity is my measure of stock price informativeness. This variable measures the degree to which the stock prices of different firms moved together in an average week in 1995. Greater synchronicity (comovement) of stock returns implies that a larger proportion of stock return variation is explained by market-wide than by firm-specific factors, suggesting that stock prices are less informative.

Information on stock market liquidity comes from the International Finance Corporation’s (IFC) Emerging Stock Markets Factbook (1996). The IFC reports stock market 
turnover, a common measure of liquidity, which is the ratio of the total value traded to total stock market capitalization. I use the IFC's turnover data for the sample countries for 1995. Table 1 describes the dependent variables.

\section{Insider Trading Regulation and Enforcement}

\section{a. Insider Trading Laws}

Since most countries with stock exchanges (and all of the countries in my sample) forbid corporate insiders to trade on the basis of price-sensitive, private information, I do not code this basic restriction. ${ }^{10}$ Rather, I code four additional elements of countries’ insider trading laws as they existed as of the mid-1990s (Gaillard, 1992; Stamp and Welsh, 1996) on the basis of a priori reasoning about which elements of insider trading laws are substantively significant, with an emphasis on deterrence. $^{11}$

The first element, Tipping, equals one if a corporate insider is liable for giving pricesensitive, private information to an outsider (so-called “tippee” ${ }^{12}$ ) and encouraging her to trade, and zero otherwise. Forbidding a corporate insider to trade on inside information but at the same time allowing her to tip outsiders who subsequently trade is equivalent to allowing the insider to trade on her own behalf. ${ }^{13}$ The second element, Tippee, equals one if tippees, like corporate insiders, are forbidden to trade on price-sensitive, private information, and zero otherwise. ${ }^{14}$ The third element, Damages, equals one if the potential monetary penalty for violating a country's

10 Price-sensitive information is generally defined as information that would significantly affect the stock's price. The standards for determining whether information is price-sensitive vary across countries and contexts, as Euronext, the pan-European Exchange, notes: "Whether or not information is price sensitive depends on factors specific to each individual company, such as its size, recent history and sector of activity. Market sentiment can also have a marked effect on price sensitivity. Given these considerations, it is not possible to produce one definition of price sensitivity that takes all of these factors into account. For the same reason, it is impossible to indicate what percentage increase or decrease in a share price qualifies as a 'significant impact' on prices" <http://www.euronext.com/vgn/images/portal/cit_53424/55/32/66175905901789_OA1_Price-sens.pdf>. Therefore, I do not code price-sensitivity (materiality) standards because to do so would require subjective judgments. I avoid coding scienter requirements and fiduciary standards for the same reason. At any rate, the requirement of a fiduciary nexus between the source of the information and the person engaging in insider trading is virtually unique to common law countries, and particularly the United States (see Chiarella v. United States, 445 U.S. 222 (1980). I do not code the misappropriation theory of liability (see United States v. O’Hagan, 521 U.S. 642 (1997)) either, for simplicity. Herrington (2004) does, however.

11 Bainbridge (1999), Brudney (1979), Clark (1986), and Kraakman (1991) provide excellent overviews of the legal doctrinal issues.

12 A tippee is an outsider who has received a "heads-up” (or tip) about price-sensitive, private information by a corporate insider (a director, manager, employee, advisor, etc.).

13 As Brudney (1979) notes, "the insider, by giving the information out selectively, is in effect selling the information to its recipient for cash, reciprocal information, or other things of value for himself, including possibly prestige or status or the like (p. 348).” 
insider trading law is greater than the illicit insider trading profits, and zero otherwise. If the potential monetary penalty is less than the profits from insider trading, the insider trading law's deterrent effect is weaker, holding constant the probability of detection. ${ }^{15}$ Finally, the fourth element, Criminal, equals one if insider trading is a criminal offense in the country, and zero otherwise. In some cases, criminal sanctions might yield more efficient deterrence than monetary sanctions (Polinksy and Shavell, 2000). ${ }^{16}$

A country's insider trading prohibition can be characterized along two broad (although not exhaustive) dimensions: the scope of the activities that it prohibits and the sanctions for violating it. I thus create two sub-indices of insider trading law, which correspond roughly to these separate aspects. The first sub-index, Scope, is the sum of Tipping and Tippee. The insider trading prohibition is broader if it prohibits insiders both from trading and from tipping third parties. It is broader still if it also forbids tippees to trade. The second sub-index, Sanction, is the sum of Damages and Criminal and is a rough proxy for the expected cost of violating a country's insider trading laws. A potential violator will compare the expected benefit to the expected cost of breaking the law (see, e.g., Becker, 1968; Polinsky and Shavell, 2000). Holding constant the expected benefit, the greater the expected cost, the greater is the law's deterrent effect. $^{17}$

I also create an aggregate insider trading law index, IT Law, which is the sum of the two sub-indices, Scope and Sanction. Abstracting from enforcement, an IT Law score of zero represents the most lax insider trading regime, while an IT Law score of four represents the most

\footnotetext{
14 "[R]eceipt of the information by one who is such a selected beneficiary taints the recipient so that he should no more be entitled to use it in trading than was the donor" (Id.).

15 Of course, the probability of detection is not constant; some countries have better detection technology than others. When the probability of detection is very low, the monetary penalty must be greater for efficient deterrence (Dooley, 1980; Easterbrook, 1985; Polinsky and Shavell, 2000). In fact, very high monetary sanctions might be desirable if they accommodate low detection probabilities and thus economize on enforcement costs (Polinsky and Shavell, 2000). In the context of shareholder litigation, Dooley (1980) discusses several negative effects of limiting recovery to insider trading profits.

16 One case is where the likelihood of detection is very low and the optimal monetary penalty is thus greater than the violator's net wealth. In such a case, criminal prosecution leading to imprisonment or other non-monetary sanctions might yield optimal deterrence (Easterbrook, 1985). Criminal sanctions might also have the opposite effect, however, since in most jurisdictions criminal prosecution requires a higher standard of proof. A higher burden of proof reduces the probability of success of prosecution and increases enforcement costs. This should reduce the likelihood of finding a statistically significant coefficient on Criminal.

17 Since I do not have data on the expected benefits of violating insider trading laws, my analysis implicitly assumes that they are constant within and across countries. In reality, insider trading profits vary systematically with legal and institutional differences across countries and the context within which such trading occurs (see, e.g., Bris 2003; Durnev and Nain, 2004).
} 
prohibitive insider trading regime. Each of the insider trading law variables is described in Table

1.

\section{b. Enforceability}

Enacting insider trading laws is merely the first step. The deterrent effect of such laws also depends on the probability (actual or perceived) that they will be enforced (see, e.g., Zimring and Hawkins, 1973). In this regard, two dimensions of enforcement are relevant: actual (or past) enforcement and enforcement power (or potential), both of which theoretically should figure in the costs of potential transgressors' calculus.

Although there is little systematic information on actual enforcement or enforcement power across countries, a few rough proxies exist. For actual enforcement, I use information on countries' enforcement histories from Bhattacharya and Daouk (2002). Their enforcement information consists of the year in which a country enforced its insider trading rules for the first time. I convert this information into the variable Enforced by 1994, which equals one if a country had enforced its insider trading rules for the first time by 1994 and zero otherwise. ${ }^{18}$

For enforcement power, I construct two separate measures: public enforcement power and private enforcement power. My division of enforcement power into public and private dimensions is inspired by the theoretical inquiry about who should enforce a particular public law (see, e.g., Glaeser, Johnson, and Shleifer, 2001; Hay and Shleifer, 1998; Landis, 1938; La Porta et al., 2003; Shavell and Polinksy, 2000). ${ }^{19}$ To construct public enforcement power, I rely on securities regulatory information compiled by La Porta et al. (2003) based on a survey of domestic lawyers concerning, among other things, the attributes and investigative powers of the

18 I choose 1994 as the cut-off date because the dependent variables come from around the period 1995-1996 and because the insider trading law indices are based on the sample countries' insider trading rules as they existed around the same period. Both the content and the enforcement of these laws might have changed in many of these countries since 1994. See Herrington (2004) for more recent measures of insider trading rules and enforcement across countries.

19 La Porta et al. (2003) address the relative advantages and disadvantages of private and public enforcement of securities laws. Under their public enforcement hypothesis, "[p]ublic enforcement might work because the enforcer is independent and focused and so can regulate markets free from political interference, because the enforcer can introduce regulations of market participants, because it can secure information from issuers and market participants - through subpoena, discovery, or other means - more effectively than private plaintiffs, or because it can impose sanctions" (p. 4). Under their private enforcement hypothesis, the main, "benefit of the securities law is the direct reduction in the costs of private contracting [since] the law can structure contracting and litigation by explicitly describing the obligations of various parties and burdens of proof, thereby reducing the costs to them and to the court of establishing liability” (pp. 3-4). 
securities market supervisor. ${ }^{20}$ The supervisor's attributes include four elements that address the supervisor's independence, focus and power: (1) supervisor appointment process; (2) supervisor tenure; (3) focus of supervisor's activities; and (4) supervisor's rulemaking authority. La Porta et al. (2003) compute the supervisor characteristics index as the mean of these four attributes. A higher mean signifies that the securities market supervisor is more independent of the political process and has greater authority. La Porta et al. (2003) also construct an index of the supervisor's investigative powers, which equals the mean of the supervisor's power to command documents and to subpoena the testimony of witnesses during investigations of violations of the country's securities laws. Using these two measures, I create the variable Public Enforcement Power as the mean of La Porta et al.'s (2003) supervisor characteristics and investigative powers indices. Table 1 describes Public Enforcement Power and its components in greater detail.

To construct a measure of private enforcement power, I first consider whether investors may bring private suits against alleged transgressors of the country's insider trading laws. Private rights to sue theoretically should increase investors' incentives to enforce the country's insider trading laws independent of any action taken by the relevant regulatory authority(ies). ${ }^{21}$ The variable Private Right equals one if such a right exists, and zero otherwise. Private litigation is only meaningful to the extent that the judicial system is reliable and efficient, however (see, e.g., Glaeser, Johnson, and Shleifer, 2001; Hay and Shleifer, 1998). Thus, I construct an index of private enforcement power, Private Enforcement Power, as the product of an index of the efficiency of the judiciary (La Porta et al., 2003) and Private Right. Table 1 describes Private Enforcement Power and its components in greater detail.

\section{Other Controls}

To isolate the relationship between insider trading regulation and the dependent variables, I control for several factors that prior research suggests are relevant to financial market structure and performance. First, since economic development is generally associated with greater financial market development and better institutions and law enforcement capabilities (see, e.g., La Porta et al., 1999; North, 1981), I control for the logarithm of per capita gross domestic

\footnotetext{
${ }^{20}$ I am implicitly assuming that the sample countries' relative rankings in terms of these measures have not changed significantly between the mid-1990s and the time of La Porta et al.'s (2003) survey.

${ }_{21}$ Of course, private enforcement might be abusive or insufficient (see, e.g., Dooley, 1980; Polinsky and Shavell, 2000). I say more about the potential insufficiency of private enforcement in the conclusion.
} 
product (GDP). ${ }^{22}$ Second, since stock market liquidity is positively associated with economic growth (Atje and Jovanovic, 1993; Levine and Zervos, 1998), I control for the growth of GDP per capita. Third, I control for anti-director rights (La Porta et al., 1997) and legal origin (La Porta et al., 1997), since La Porta et al. $(1997,1998)$ demonstrate that both measures have an important bearing upon financial development. Finally, I control for disclosure, since better disclosure is associated with greater stock market development (Francis, Khurana and Pereira, 2003; La Porta et al., 1997, 1998, 2003) and might reduce corporate insiders' incentives to engage in insider trading (Baiman and Verrecchia, 1996; Shin, 1996).

I use two measures of disclosure. The first is a measure of legal disclosure requirements from La Porta et al. (2003). This index, Disclosure, is an arithmetic average of 5 categories of information that firms are required to include in their offering prospectuses: (1) compensation; (2) ownership structure; (3) inside ownership; (4) irregular contracts; and (5) related party transactions. The second measure is the quality of accounting standards, Accounting, which ranks countries on the basis of the quality of their corporate disclosure practices as of 1990 (La Porta et al., 1998). Disclosure is a proxy for the strength of the involuntary disclosure regime at the initial offering stage, while Accounting is a proxy for the quality of periodic (post-offering) disclosure and measures firms' actual disclosure practices rather than legal disclosure requirements per se. Table 1 describes both disclosure variables and all of the other control variables in greater detail.

\section{Univariate Statistics}

Table 2 presents the formal insider trading laws and enforcement measures for the sample countries, grouped by legal origin. The only significant difference in the formal insider trading laws between the common law countries and the civil law countries is with respect to sanctions. The difference in the mean value of Sanction (the sum of Damages and Criminal) between the common law and civil law countries is positive and significant at the $10 \%$ level. The common law countries also tend to allocate greater public and private ${ }^{23}$ enforcement power (the differences in the mean values of both of these variables are significant at the $1 \%$ level). These patterns are consistent with the general finding of La Porta et al. $(1997,1998)$ that common law

22 Also, wealthier countries should have (access to) more advanced surveillance technologies to detect insider trading violations. 
countries are more protective of investors than civil law countries. However, there is no significant difference in the proportion of the common law countries that had enforced their insider trading laws by 1994 and the proportion of the civil law countries that had done so.

Table 3 presents pair-wise correlation coefficients. Consistent with H1, ownership dispersion is positively and significantly correlated with the aggregate IT Law index, the subindex Sanction, and Enforced by 1994 (the correlation coefficients have p-values of 0.01, 0.00 and 0.00 , respectively). Ownership dispersion is not significantly correlated with either of the enforcement power variables, Public Enforcement Power and Private Enforcement Power, although the correlation coefficients are all positive, consistent with H1. Consistent with H2, stock price synchronicity is negatively ${ }^{24}$ and significantly correlated with the aggregate IT Law index and the sub-indices Sanction and Scope (the correlation coefficients have p-values of 0.01, 0.04 and 0.03 , respectively). However, stock price synchronicity is not significantly correlated with any of the actual or enforcement power measures. Consistent with H3, stock market turnover is positively correlated with the sub-index Scope and the aggregate IT Law index (the correlation coefficients have p-values of 0.04 and 0.03 , respectively). However, stock market turnover is not significantly correlated with Sanction or with any of the enforcement measures (column 5 and rows 7-9).

Finally, the results in Table 3 suggest that countries whose formal insider trading laws penalize insider trading more harshly also tend to allocate greater enforcement powers to both public and private enforcers and are more likely to have actually enforced such laws.

\section{DO INSIDER TRADING LAWS MATTER?}

\section{A. Ownership Dispersion}

H1 predicts that countries with more prohibitive insider trading laws have more dispersed stock ownership. Panel A of Table 4 presents the basic regressions for ownership dispersion. Columns 1-3 present the results using the alternative insider trading law indices and the control variables, excluding the disclosure variables. The coefficient on Scope is negative and insignificant (column 1). In contrast and consistent with H1, the coefficient on Sanction is

\footnotetext{
23 I thank Merritt Fox for pointing out that "countries that have a private right of action to support rules against insider trading probably have a quite different kind of legal system in other broader regards.” I control for legal origin in the regressions, which should partially address this concern.

$24 \quad \mathrm{H} 2$ predicts a negative correlation between the stringency of insider trading laws and synchronicity because lower synchronicity implies that stock prices are more informative.
} 
positive and significant at the $1 \%$ level (column 2). Also consistent with $\mathrm{H} 1$, the coefficient on the aggregate index IT Law is positive and significant at the 5\% level (column 3).

In columns 4-9 in Panel A of Table 4, I regress ownership dispersion on the alternative insider trading law measures, the disclosure variables and the other control variables. When I control for Disclosure and Accounting, the coefficient on Scope remains insignificant (columns 4 and 5, respectively); the coefficient on Sanction remains positive and significant (columns 6 and 7, respectively); and the coefficient on the aggregate IT Law index remains positive and significant (columns 8 and 9, respectively). The coefficients on the disclosure variables are generally insignificant (columns 4-9). ${ }^{25}$ Overall, the results in Panel A of Table 4 are consistent with $\mathrm{H} 1$ and suggest that large public corporations tend to have greater ownership dispersion in countries whose formal insider trading laws contain greater sanctions for insider trading violations.

\section{B. Stock Price Informativeness}

$\mathrm{H} 2$ predicts that stock prices are more informative in markets with more stringent insider trading laws. Lower synchronicity implies more informative stock prices, so H2 predicts negative regression coefficients on the insider trading law variables. Panel B of Table 4 presents the basic regressions for stock price synchronicity. Columns 1-3 of Panel B regress stock price synchronicity on the alternative insider trading law indices and the control variables, excluding the disclosure variables. Consistent with H2, the coefficient on Scope is negative and significant at the 5\% level (column 1). Also consistent with H2, the coefficient on Sanction is negative and significant at the $1 \%$ level (column 2). Again, consistent with $\mathrm{H} 2$, the coefficient on the aggregate IT Law index is negative and significant at the 5\% level (column 3).

In columns 4-9 in Panel B of Table 4, I regress stock price synchronicity on the alternative insider trading law measures and the control variables, including the alternative disclosure variables, Disclosure and Accounting. ${ }^{26}$ The coefficients on Scope, Sanction, and the

25 In unreported regressions, I regress ownership dispersion on the alternative disclosure measures and the control variables, excluding the insider trading law indices. The coefficient on Disclosure is positive and significant at the $10 \%$ level. In contrast, although the coefficient on Accounting is positive, it is insignificant. My finding in this paper that the relationship between insider trading laws and the dependent variables is generally stronger than the relationship between the dependent variables and disclosure is consistent with the finding of Francis, Khurana and Pereira (2003) that disclosure is of secondary importance to the legal rules protecting investors.

${ }_{26}$ In unreported regressions, I regress stock price synchronicity on the alternative disclosure measures and the control variables, without the insider trading law indices. The coefficient on Disclosure is positive but insignificant, while the coefficient on Accounting is positive and significant at the $5 \%$ level. 
aggregate IT Law index remain negative and significant when I control for Disclosure in each of columns 4-9. The overall picture in Panel B of Table 4 is that, consistent with H2, the degree of informativeness of stock prices is positively associated with more prohibitive formal insider trading rules.

\section{Stock Market Liquidity}

H3 predicts that countries with more prohibitive insider trading laws have more liquid stock markets. Panel C of Table 4 presents the basic results. In columns 1-3 of Panel C, I regress stock market turnover on the alternative insider trading law indices and the control variables, excluding the disclosure variables. The coefficient on Scope is positive but insignificant (column 1). Consistent with H3, the coefficients on Sanction (column 2) and the aggregate IT Law index (column 3) are both positive and significant at the $10 \%$ level.

In columns 4-9 in Panel C, the regressions include the alternative insider trading law measures and the control variables, including the disclosure variables, Disclosure and Accounting. ${ }^{27}$ The coefficient on Scope remains positive but insignificant when I control for Disclosure (column 4) and becomes positive and significant at the $10 \%$ level when I control for Accounting (column 5). The coefficient on Sanction is still positive and significant at the 10\% level when I control for Disclosure (column 6), but it becomes slightly less significant ( $p$-value of 11\%) when I control for Accounting (column 7). The coefficient on the aggregate IT Law index remains positive and significant at the $10 \%$ level when I control for Disclosure and Accounting (columns 8 and 9, respectively). The results in Panel C of Table 4 suggest that, consistent with H3, countries with more prohibitive formal insider trading laws have more liquid stock markets.

\section{Are the Basic Results Robust to the Enforcement Environment?}

Thus far, I have focused on countries' formal insider trading laws. However, enforceability might be more pivotal than the formal rules (Pistor, Raiser, and Gelfer, 2000). Therefore, in Table 5, I control for the enforcement measures that I describe in Part III. These measures should capture (at least in part) omitted institutional characteristics of the securities regulatory regime that might be driving the results.

27 In unreported regressions, I regress stock market turnover on each the alternative disclosure quality measures and the other control variables, excluding the insider trading law variables. The coefficients on Disclosure and Accounting are both positive but insignificant. 
Panel A of Table 5 reports the results for ownership dispersion. Columns 1-3 include the alternative enforcement measures and the control variables without the insider trading law indices. Only past enforcement, Enforced by 1994, is positive and significant (at the 5\% level, column 1), implying that ownership is more dispersed in countries that have enforced their insider trading laws in the past. In contrast, neither Public Enforcement Power nor Private Enforcement Power is significant (columns 2 and 3, respectively). In columns 4-6, the regressions include Scope and the enforcement measures; neither Scope nor any of the enforcement measures is significant. In columns 7-9, the regressions include Sanction and the enforcement measures; the coefficient on Sanction is still positive and significant at the $1 \%$ level, while past enforcement, Enforced by 1994, is still the only significant enforcement measure (column 7). Finally, in columns 10-12, I include the aggregate IT Law index and the enforcement measures; the coefficient on the aggregate IT Law index remains positive and significant in each of these regressions, as does the coefficient on past enforcement (column 10). In short, controlling for the enforcement environment does not alter the ownership results relative to the basic regressions in Panel A of Table 5. Sanctions remain the dominant aspect of formal insider trading laws vis-à-vis ownership dispersion.

Panel B of Table 5 reports the results for stock price synchronicity. In columns 1-3, I regress stock price synchronicity on the enforcement variables without the insider trading law measures. Public Enforcement Power is negative and significant at the 5\% level (column 2), implying that greater public enforcement power is associated with more informative stock prices. In contrast, neither Enforced by 1994 nor Private Enforcement Power is significant (columns 1 and 3, respectively). In columns 4-6, the regressions include Scope and the enforcement measures; the coefficient on Scope becomes insignificant (but is still negative) when I control for Public Enforcement Power (column 5) and none of the coefficients on the enforcement measures is significant. In columns 7-9, the regressions include Sanction and the enforcement measures; the coefficient on Sanction remains negative and significant, except in column 8, where it becomes less significant (with a p-value of 12\%) when I control for Public Enforcement Power, which is insignificant. Finally, in columns 10-12, the regressions include the aggregate IT Law index and the enforcement variables; the coefficient on the aggregate IT Law index remains negative and significant, except in column 11, where it becomes less significant (with a $p$-value of 11\%) when I control for Public Enforcement Power, which is insignificant. 
Panel C of Table 5 reports the results for stock market liquidity. In columns 1-3, I regress stock market turnover on the enforcement variables without the insider trading law measures. The coefficient on Public Enforcement Power is positive and significant at the 10\% level (column 2), implying that greater public enforcement power is associated with more liquid stock markets. In contrast, the coefficients on Enforced by 1994 and Private Enforcement Power are both insignificant (columns 1 and 3, respectively). ${ }^{28}$

In columns 4-6, the regressors include Scope and the alternative enforcement measures; the coefficients on Scope and the enforcement measures are all positive but insignificant. In columns 7-9, the regressions include Sanction and the enforcement measures. The coefficient on Sanction remains positive and significant at the $10 \%$ level when I control for Private Enforcement Power (column 9). In contrast, the coefficient on Sanction becomes insignificant when I control for both Enforced by 1994 (column 7) and Public Enforcement Power (column 8), neither of which is significant. Finally, in columns 10-12, the regressions include the aggregate IT Law index and the alternative enforcement measures. The coefficient on the aggregate IT Law index remains positive and significant at the $10 \%$ level when I control for Private Enforcement Power (column 12), but becomes slightly less significant ( $p$-value of 11\%) when I control for past enforcement (column 10) and completely insignificant when I control for Public Enforcement Power (column 11).

Table 5 shows that the basic results are robust to controlling for past enforcement and private enforcement power, but not public enforcement power. The results for stock price synchronicity and especially stock market turnover (but not ownership dispersion) are mitigated when I take into account public enforcement power. It turns out, however, that Public Enforcement Power is highly correlated with Sanction (and thus with the aggregate IT Law index), which means that the two variables cannot really be disentangled. This could explain why, in the liquidity and synchronicity regressions, each is significant without the other but both are insignificant when they are included together. To address this problem, I code a new variable, the product of Public Enforcement Power and Sanction. ${ }^{29}$ As Table 6 demonstrates, the

\footnotetext{
28 In contrast, Bhattacharrya and Daouk (2002) find that past enforcement of insider trading laws is associated with a positive and statistically significant increase in stock market liquidity. The difference between their results and mine is not altogether surprising, however. Because their data cover many countries over more than twenty years, they have a very large sample size. The low level of statistical significance of the coefficient on Enforced by 1994 undoubtedly results from my small sample size, which reduces the power of the statistical tests.

29 The results are similar if I take their sum. See SAS (1999).
} 
combined measure is highly significant and trumps both Disclosure ${ }^{30}$ and Private Enforcement Power in full regressions for all of the dependent variables.

In summary, then, the basic results are robust to controlling for the enforcement environment. The possibility of stringent sanctions (especially criminal sanctions), rather than the breadth of the prohibition, seems to be the pivotal feature of the insider trading prohibition.

\section{DISCUSSION AND FUTURE RESEARCH}

I find that countries with more prohibitive formal insider trading laws tend to have more dispersed equity ownership (H1), more informative stock prices (H2) and more liquid stock markets (H3), even when accounting for disclosure and enforceability. My results are consistent with and supplement those of Bhattacharya and Daouk (2002) in that both enforceability and formal insider trading laws seem matter to stock market development. ${ }^{31}$ Moreover, the most important aspects of the formal laws seem to be their deterrent elements, especially the possibility of criminal sanctions. Thus, while Bhattacharya and Daouk (2002) argue that the mere enactment of insider trading laws does not matter, it appears that enactment of the "right" laws does. ${ }^{32}$ Finally, my results suggest some of the particular channels (i.e., greater ownership dispersion, liquidity, and stock price informativeness) through which effective insider trading regulation might lower the cost of equity (Bhattacharya and Daouk, 2002). However, further empirical work (including case studies) covering more countries and time periods is required before I would confidently make policy recommendations.

The specific mechanisms through which countries enforce their insider trading laws merit further study. My legal measures do not incorporate liability rules, allocations of evidentiary burdens or general rules of litigation and administrative procedure, which could pose greater or lesser obstacles to private suits and public enforcement. In addition, my measure of public enforcement power (from La Porta et al., 2003) addresses general characteristics of the securities market supervisor rather than supervisor characteristics specific to insider trading oversight and

\footnotetext{
30 I do not include Disclosure in Table 6 because it is also highly correlated with Public Enforcement Power. However, the results in Table 6 do not change if I include it.

31 My data suggest that there is a strong positive correlation between the securities regulatory environment and the stringency of the formal laws.

32 This supports Polinsky and Shavell (2000), who argue that a very low probability of enforcement might be optimal if the legal sanctions are sufficiently large.
} 
enforcement. ${ }^{33}$ I acknowledge such shortcomings and encourage further empirical study of these additional dimensions.

Nevertheless, my preliminary findings arguably shed some initial light on the question “[w]ho should enforce a particular legal rule?” (Glaeser, Johnson, and Shleifer, 2001) in the context of insider trading. Hay and Shleifer (1998) argue that private enforcement of public laws is superior to public enforcement of such laws when the state's legal apparatus is dysfunctional. Consistent with the latter rationale, La Porta et al. (2003) find that private enforcement of securities laws governing new equity offerings is more effective than public enforcement of such laws. In contrast, my findings suggest that public enforcement (especially the legal and institutional ability to levy criminal sanctions) is more important than private enforcement of insider trading laws. This result is not surprising, since many features of insider trading render it more amenable to public enforcement. ${ }^{34}$

Two additional enforcement mechanisms that I have not considered here are selfregulation by stock exchanges (self-regulatory organizations (SROs)) and private ordering. On the one hand, via their proprietary, real-time electronic trading data, SROs might be better able to identify insider trading and might have greater incentives, relative to the state and private investors, to write and enforce securities market rules (Mahoney, 1997). On the other hand, SROs might have conflicted interests (Kahan, 1997), especially if their owners/members (i.e., broker-dealers) are the very parties who engage in insider trading (Haddock and Macey, 1987). Also, spillovers (Cooter, 1996) might cause SROs to under-enforce, especially in light of market fragmentation (Harris, 1993). Finally, SROs lack the police force necessary to compel information, capture violators and impose non-monetary sanctions, like imprisonment. ${ }^{35}$ The

33 The latter data are extremely hard to get, although Herrington (2004) makes some initial strides in this direction.

34 In particular, individual investors are unable to discern insider trading in impersonal markets and are therefore unlikely to exercise private rights of action, even in countries with efficient judicial systems. As Dooley (1980) notes for the United States, "private actions play a trivial role in regulating insider trading; the Commission [SEC] has a virtual monopoly. The private actions actually brought are largely parasitic - a condition found nowhere else in securities regulation. Even with the benefit of prior SEC action, private parties are surprisingly reluctant to bring claims” (pp. 16-17). Consequently, “[p]rivate suits have little deterrent effect independent of what can be produced at less cost by public enforcement and must be justified, if at all, on compensatory grounds” (Dooley, 1980, p. 36). This is consistent with Landis (1938) and Polinsky and Shavell (2000), who argue that public enforcement is optimal when it is too costly for the victim to identify or apprehend the perpetrator.

35 In practice, many stock exchanges (like the NYSE) cooperate with public regulators to enforce insider trading rules (see, e.g., Dooley, 1980). 
role of SROs in insider trading rulemaking and enforcement is thus an interesting question that merits future comparative study. ${ }^{36}$

Private contracting between firms and shareholders (as opposed to a mandatory prohibition) is another way that countries might address insider trading (see, e.g., Carlton and Fischel, 1983; Haddock and Macey, 1986a). Breaches of insider trading “contracts” presumably would be settled in court. ${ }^{37}$ However, since public regulation has generally supplanted any private ordering of insider trading, ${ }^{38}$ this method of enforcement is not very amenable to empirical analysis (Cox, 1986; Easterbrook, 1985), except perhaps from an historical perspective. $^{39}$ Also, the preceding analysis of the relative efficacy of private and public enforcement of public insider trading rules applies with equal force to private ordering (Cox, 1986; Easterbrook, 1985).

Another issue worthy of further study is the political economy of insider trading laws. The public choice claim that various stakeholders in the financial system cause these laws to be adopted (Haddock and Macey, 1987) suggests that causality might instead run from the financial system to insider trading rules. ${ }^{40}$ (The fact that the basic results appear to be robust to changing the time period in which the dependent variables are measured ${ }^{41}$ and the legal origin controls should partially address this critique with respect to my data, however.) It is also possible that some countries enacted insider trading laws merely in response to external pressure (Haddock and Macey, 1986b), resulting in rote transplantation of foreign laws unrelated to the country's financial, legal, and institutional characteristics (see, e.g., Pistor, 2002). (However, my finding

36 Herrington (2004) is the first study I am aware of that considers SRO enforcement. His results suggest that SRO enforcement is generally not strongly related to the financial variables in this study.

37 " [I]t is not at all clear...that the current enforcement apparatus of the [SEC] is necessary to supplement in the common law courts the regime of private enforcement that would take place if a 'Coasian' system of private contracting were permitted to exist” (Haddock and Macey, 1986a, p. 1451). However, private ordering of insider trading would raise several concerns, including: difficulty of shareholders to detect breaches of insider trading agreements (Cox, 1986); judicial and transaction uncertainty caused by the absence of a bright line rule, which could pose particular problems in transition economies (Shleifer and Hay, 1998); externalities (Easterbrook, 1985); and potential reinforcement of undesirable social norms (Cooter, 1997; Posner, 1996; Shleifer and Hay, 1998).

38 For example, Germany apparently had a system of private contracting prior to its adoption of a statutory insider trading law (Schafer and Ott, 1992).

39 According to Easterbrook (1985), “[t]he [U.S.] historical pattern - trading until 1961, public enforcement thereafter - is consistent with a story that trading is efficient, but it is equally consistent with a story that public enforcers have a comparative advantage, aided by computers and the criminal law, in getting rid of an inefficient practice” (p.95).

40 Coffee (2001) addresses this issue more generally.

41 Herrington (2004) runs similar regressions of 2003 measures of synchronicity and liquidity using my insider trading indices for a larger sample of 49 countries and obtains qualitatively similar results. 
of a significant relationship between formal insider trading laws and financial structure and performance suggests otherwise, at least for the countries in my sample.) Since both endogeneity and irrelevance of formal insider trading laws are plausible alternatives to the story here, careful study of the political economy of countries' (especially emerging markets') adoption of insider trading laws would therefore be informative (see, e.g., Beny, 2002, for a start).

Finally, it might be worth exploring the interaction between insider trading laws and business norms. The enforceability critique of formal laws (Pistor, Raiser, and Gelfer, 2000) notwithstanding, the rarity of enforcement (Bhattacharya and Daouk, 2002) might not prove noncompliance in every context (Cooter, 1998, 2000). From an expressive perspective, insider trading laws might "tip a system of social norms into a new equilibrium” (Cooter, 1998). Among other things, therefore, one could examine countries' official pronouncements accompanying their prohibition of insider trading. Such pronouncements (or lack thereof) might illuminate whether they are trying to promote the best global business norms or simply appeasing imperial prerogatives. 
References

Akerlof, George. 1970. “The Market for 'Lemons': Quality Uncertainty and the Market Mechanism”, 84 Quarterly Journal of Economics 488-500.

Atje, Raymond and Boyan Jovanovic. 1993. “Stock Markets and Development,” 37 European Economic Review 632-640.

Ausubel, Lawrence M. 1990. "Insider Trading in a Rational Expectations Economy,” 80 American Economic Review 1022-1041.

Baiman, Stanley and Robert E. Verrecchia. 1996. “The Relation Among Capital Markets, Financial Disclosure, Production Efficiency, and Insider Trading,” 343 Journal of Accounting Research 1-22.

Bainbridge, Stephen M. 1999. Securities Law: Insider Trading. New York: Foundation Press.

Bebchuk, Lucian A. and Chaim Fershtman. 1990. “The Effect of Insider Trading on Insiders' Reaction to Opportunities to 'Waste’ Corporate Value,” John M. Olin Center for Law, Economics and Business Working Paper 76, Harvard Law School.

Becker, Gary S. 1968. “Crime and Punishment: An Economic Approach,” 76 Journal of Political Economy 169-217.

Benabou, Roland and Guy Laroque. 1992. “Using Privileged Information to Manipulate Markets: Insiders, Gurus, and Credibility,” 107 Quarterly Journal of Economics 921-948.

Beny, Laura N. 1999. “A Comparative Empirical Investigation of Agency and Market Theories of Insider Trading,” John M. Olin Center for Law, Economics and Business Working Paper 264, Harvard Law School

. 2002. “The Political Economy of Insider Trading Legislation and Enforcement: International Evidence,” John M. Olin Center for Law, Economics and Business Working Paper 348, Harvard Law School.

Bhattacharya, Utpal and Hazem Daouk. 2002. “The World Price of Insider Trading,” 57 Journal of Finance 75-108.

Bhide, Amar. 1993. “The Hidden Costs of Stock Market Liquidity,” 34 Journal of Financial Economics 31-51.

Bris, Arturo. 2003. “Do Insider Trading Laws Work?” Yale International Center for Finance Working Paper. 
Brudney, Victor. 1979. "Insiders, Outsiders, and Informational Advantages Under the Federal Securities Laws,” 93 Harvard Law Review 322-376.

Bushman, Robert M., Joseph D. Piotroski, and Abbie J. Smith. 2005. "Insider Trading Restrictions and Analysts’ Incentives to Follow Firms,” 60 Journal of Finance 35-66.

Chiarella v. United States, 445 U.S. 222 (1980).

Carlton, Dennis W. and Daniel R. Fischel, 1983. "The Regulation of Insider Trading," 35 Stanford Law Review 857-895.

Clark, Robert. 1986. Corporate Law. Boston: Little, Brown \& Co.

Coffee, John C. 2001. "The Rise of Dispersed Ownership: The Roles of Law and the State in the Separation of Ownership and Control," 111 Yale Law Journal 3-82.

Cooter, Robert D. 1996. "Decentralized Law for a Complex Economy: The Structural Approach to Adjudicating the New Law Merchant," 144 University of Pennsylvania Law Review 1643-1696. . 1997. "Normative Failure Theory of Law,” 82 Cornell Law Review 947-979. . 1998. “Expressive Law and Economics,” 27 Journal of Legal Studies 585-608.

. 2000. "Three Effects of Social Norms on Law: Expression, Deterrence, and Internalization,” 79 Oregon Law Review 1-22.

Copeland, Thomas E. and Dan Galai. 1983. Information Effects on the Bid-Ask Spread, 38 Journal of Finance 1457-1469.

Cox, James D. 1986. "Insider Trading and Contracting: A Critical Response to the Chicago School,” 1986 Duke Law Journal 628-659.

Demsetz, Harold. 1986. “Corporate Control, Insider Trading, and Rates of Return,” 76 American Economic Review 313-316.

Dooley, Michael P. 1980. "Enforcement of Insider Trading Restrictions," 66 Virginia Law Review 1-89.

Durnev, Artyom and Amrita Nain. 2004. "The Unanticipated Effects of Insider Trading Regulation.” Working Paper, University of Michigan.

Easterbrook. 1985. "Insider Trading as an Agency Problem,” in Pratt, John W. and Richard J. Zeckhauser, eds. Principles and Agents: The Structure of Business. Boston: Harvard Business School Press, 81-100. 
Fishman, Michael J. and Kathleen M. Hagerty. 1992. “Insider Trading and the Efficiency of Stock Prices,” 23 Rand Journal of Economics 106-122.

Francis, Jere R., Inder Khurana, and Raynolde Pereira. 2004. "The Role of Accounting and Auditing in Corporate Governance and the Development of Financial Markets Around the World,” 10 Asia-Pacific Journal of Accounting and Economics 1-30.

French, Kenneth R. and Richard Roll. 1986. "Stock Return Variances: The Arrival of Information and the Reaction of Traders,” 17 Journal of Financial Economics 5-26.

Gaillard, Emmanuel, ed. 1992. Insider Trading: The Laws of Europe, the United States, and Japan. Boston: Kluwer Law and Taxation Publishers.

Georgakopoulos, Nicholas L. 1993. "Insider Trading as a Transactional Cost: A Market Microstructure Justification and Optimization of Insider Trading Regulation,” 26 Connecticut Law Review 1-51.

Glaeser, Edward, Simon Johnson, and Andrei Shleifer. 2001. “Coase versus the Coasians,” 116 Quarterly Journal of Economics 853-899.

Glosten, Lawrence R. and Lawrence E. Harris. 1988. "Estimating the Components of the Bid/Ask Spread,” 21 Journal of Financial Economics 123-142.

Goshen, Zohar and Gideon Parchomovsky. 2001. “On Insider Trading, Markets, and 'Negative’ Property Rights in Information,” 87 Virginia Law Review 1229-1277.

Grossman, Sanford. 1976. “On the Efficiency of Competitive Stock Markets Where Traders Have Diverse Information,” 31 Journal of Finance 573-85.

Haddock, David D. and Jonathan R. Macey. 1986a. “A Coasian Model of Insider Trading,” 80 Northwestern University Law Review 1449-1472. . 1986b. "Controlling Insider Trading in Europe and America: The Economics of the Politics,” in Graf von der Schulenburg, J. Matthias, and Goran Skogh, eds. Law and Economics and the Economics of Legal Regulation. Dordrecht: Kluwer, 149-167.

_. 1987. "Regulation on Demand: A Private Interest Model with an Application to Insider Trading Regulation,” 30 Journal of Law and Economics 311-352.

Haft, Robert J. 1982. "The Effect of Insider Trading Rules on the Internal Efficiency of the Large Corporation,” 80 Michigan Law Review 1051-1071.

Harris, Lawrence. 1993. “Consolidation, Fragmentation, Segmentation and Regulation,” 2 Financial Markets, Institutions and Instruments, 3-28. 
Hay, Jonathan R. and Andrei Shleifer. 1998. "Private Enforcement of Public Laws: A Theory of Legal Reform,” 88 American Economic Association Papers and Proceedings 398-403.

Herrington, Duncan. 2004. “Insider Trading Enforcement and Market Performance,” Harvard Law School mimeo.

International Finance Corporation. 1996. Emerging Stock Markets Factbook.

Kahan, Marcel. 1997. “Some Problems with Stock Exchage-Based Securities Regulation,” 83 Virginia Law Review, 1509-1519.

Kraakman, Reinier. 1991. "The Legal Theory of Insider Trading Regulation in the United States,” in Hopt, Klaus J. and Eddy Wymeersch, eds. European Insider Dealing. London: Butterworths, 39-55.

Landis, James M. 1938. The Administrative Process. New Haven, CT: Yale University Press.

La Porta, Rafael, Florencio Lopez-de-Silanes, Andrei Shleifer, and Robert Vishny. 1997. “Legal Determinants of External Finance,” 52 Journal of Finance 1131-1150. . 1998. “Law and Finance,” 106 Journal of Political Economy 1113-1155. . 1999, The Quality of Government, Journal of Law, Economics and Organization 15, 222-279.

La Porta, Rafael, Florencio Lopez-de-Silanes, and Andrei Shleifer. 2003. "What Works in Securities Laws,” Tuck School of Business at Dartmouth Working Paper 03-22.

Leland, Hayne. 1992. “Insider Trading: Should it be Prohibited?” 100 Journal of Political Economy 859-887.

Levine, Ross and Sara Zervos. 1998. “Stock Markets, Banks and Economic Growth,” 88 American Economic Review, 537-558.

Mahoney, Paul G. 1997. “The Exchange as Regulator,” 83 Virginia Law Review 1453-1500.

Manne, Henry G. 1966. Insider Trading and the Stock Market. New York: Free Press.

Manove, Michael. 1989. “The Harm from Insider Trading and Informed Speculation,” 104 Quarterly Journal of Economics 823-845. . 2002. “Insider Trading Legislation and Corporate Governance,” 46 European Economic Review 1569-1597.

Morck, Randall, Bernard Yeung, and Wayne Yu. 2000. “The Information Content of Stock Markets: Why Do Emerging Markets Have Synchronous Stock Price Movements?” 58 Journal of Financial Economics 215-260. 
North, Douglas. 1981. Structure and Change in Economic History. New York: Norton.

Pistor, Katharina. 2002. "The Standardization of Law and Its Effect on Developing Economies,” 50 American Journal of Comparative Law 97-130.

Pistor, Katharina, Martin Raiser, and Stanislaw Gelfer. 2000. "Law and Finance in Transition Economies,” 8 The Economics of Transition, 325-368.

Polinsky, A. Mitchell and Steven Shavell. 2000. "The Economic Theory of Public Enforcement of Law,” 38 Journal of Economic Literature 45-76.

Posner, Eric A. 1996. Law, Economics and Inefficient Social Norms, 144 University of Pennsylvania Law Review 1697-1744.

Roll, Richard. 1988. " $\mathrm{R}^{2}$,” 43 Journal of Finance 541-566.

SAS Institute Inc. 1999. SAS/STAT User's Guide. Cary, NC: SAS Institute Inc.

Schafer, Hans-Bernd and Claus Ott. 1992. "Economic Effects of EEC Insider Trading Regulation Applied to Germany,” 12 International Review of Law and Economics, 357375.

Shin, Jhinyoung. 1996. "The Optimal Regulation of Insider Trading,” 5 Journal of Financial Intermediation 49-73.

Shleifer, Andrei and Robert Vishny. 1986. "Large Shareholders and Corporate Control,” 94 Journal of Political Economy 461-488. . 1997. "The Limits of Arbitrage," 52 Journal of Finance 35-55.

Stamp, Mark and Carson Welsh, eds. 1996. International Insider Dealing. London: FT Law \& Tax.

Stoll, Hans. 1989. "Inferring the Components of the Bid-Ask Spread: Theory and Empirical Tests,” 44 Journal of Finance 115-134.

United States v. O’Hagan, 521 U.S. 642 (1997))

World Bank. Various Years. Global Development Indicators CD-ROM.

Wurgler, Jeffrey. 2000. "Financial Markets and the Allocation of Capital," 58 Journal of Financial Economics 187-214.

Zimring, Franklin E. and Gordon J. Hawkins. 1973. Deterrence: The Legal Threat in Crime Control. Chicago: University of Chicago Press. 


\title{
Table 1: Description of the Variables
}

\author{
Description
}

\section{Dependent Variables}

Ownership

Dispersion

Stock Market

Turnover

Stock Price

Synchronicity

Tipping

Tippee

Damages

Criminal

Scope

Sanction

IT Law

Enforced by 1994

Public

Enforcement

Power
One minus the average fraction of common stock of the ten largest non-financial domestic firms owned by the three largest shareholders in the country. Source: La Porta et al. (1998).

The total value traded divided by stock market capitalization in 1995. Source: International Finance Corporation, Emerging Stock Markets Factbook (1996).

The fraction of stocks whose prices moved in the same direction in an average week in 1995. Source: Morck, Yeung, and Yu (2000).

\section{$\underline{\text { Insider Trading Law Variables }}$}

Tipping equals one if corporate insiders are prohibited from tipping outsiders (tippees) about material nonpublic information and/or encouraging them to trade on such information for personal gain; equals zero otherwise. Sources: Gaillard (1992); Stamp and Welsh (1996).

Tippee equals one if tippees, like corporate insiders, are prohibited from trading on material non-public information that they have received from corporate insiders; equals zero otherwise. Sources: Gaillard (1992); Stamp and Welsh (1996).

Damages equals one if the monetary penalty for violating insider trading laws is potentially greater than the insiders' trading profits; equals zero otherwise. Sources: Gaillard (1992); Stamp and Welsh (1996).

Criminal equals one if violation of insider trading laws is a potential criminal offense; equals zero otherwise. Sources: Gaillard (1992); Stamp and Welsh (1996).

Scope is a sub-index of insider trading law. Scope measures the breadth of the insider trading prohibition. It is the sum of Tipping and Tippee. Scope ranges from 0 to 2, with 0 representing the most permissive insider trading prohibition and 2 representing the most restrictive insider trading prohibition.

Sanction is a sub-index of insider trading law. Sanction is a proxy for the expected criminal and monetary sanctions for violating a country's insider trading laws. It is the sum of Damages and Criminal. Sanction ranges from 0 to 2, with 0 representing the lowest expected sanctions and 2 representing the highest expected sanctions.

The aggregate IT Law index equals the sum of (1) Tipping; (2) Tippee; (3) Damages; and (4) Criminal; or, equivalently, the sum of Scope and Sanction. IT Law ranges from 0 to 4, with 0 representing the most lax insider trading legal regime and 4 representing the most restrictive insider trading legal regime.

\section{Enforcement Variables}

A proxy for actual enforcement, Enforced by 1994 is an indicator variable that equals one if the country's insider trading law has been enforced for the first time by the end of 1994. Source: Bhattacharya and Daouk (2002).

The public enforcement index is the arithmetic mean of an index of the securities market supervisor's characteristics and an index of the securities market supervisor's investigative powers.

The securities market supervisor's characteristics index equals the arithmetic mean of the four components: (1) Appointment - "[e]quals one if a majority of the members of the Supervisor are unilaterally appointed by 
the Executive branch of government; equals zero otherwise"; (2) Tenure - "[e]quals one if members of the Supervisor cannot be dismissed at the will of the appointing authority; equals zero otherwise; (3) Focus "[e]quals one if separate government agencies or official authorities are in charge of supervising commercial banks and stock exchanges; equals zero otherwise; (4) Rules - "[e]quals one if the Supervisor can generally issue regulations regarding primary offerings and/or listing rules on stock exchanges without prior approval of other governmental authorities. Equals one-half if the Supervisor can generally issue regulations regarding primary offerings and/or listing rules on stock exchanges only with the prior approval of other governmental authorities. Equals zero otherwise.”

The supervisor's investigative powers index equals the arithmetic mean of two factors: (1) Document - "[a]n index of the power of the Supervisor to command documents when investigating a violation of securities laws. Equals one if the Supervisor can generally issue an administrative order commanding all persons to turn over documents; equals one-half if the Supervisor can generally issue an administrative order commanding publicly-traded corporations and/or their directors to turn over documents; equals zero otherwise; (2) Witness - "[a]n index of the power of the Supervisor to subpoena the testimony of witnesses when investigating a violation of securities laws. Equals one if the Supervisor can generally subpoena all persons to give testimony; equals one-half if the Supervisor can generally subpoena the directors of publiclytraded corporations to give testimony; equals zero otherwise.”

Source: La Porta et al. (2003)

Private Right Private right equals one if private parties have a private right of action against parties who have violated the country’s insider trading laws. Sources: Gaillard (1992); Stamp and Welsh (1996).

Efficiency of the Efficiency of the judiciary is a measure of the "efficiency and integrity of the legal environment as it affects Judiciary business, particularly foreign firms.” It is recorded as the arithmetic average between 1980 and 1983. Source: La Porta et al. (2003).

Private The product of Private Right and Efficiency of the Judiciary.

Enforcement

Power

\section{$\underline{\text { Control Variables }}$}

Log of GDP Logarithm of per capita gross domestic product in 1995, measured in constant 1995 US \$. Source: World Bank, World Development Report CD-Rom (2003).

GDP Growth $\quad$ Average annual percentage growth rate of per capita GDP for the years 1970-1993. Source: World Bank, World Development Report (1995).

Anti-director The index is created by adding 1 if: (1) shareholders are allowed to mail their proxy votes; (2) the law does Rights not require shareholders to deposit their shares before the general meeting of shareholders; (3) the law permits cumulative voting; (4) a mechanism for oppressed minority shareholders exists; or (5) the minimum percentage ownership stake that entitles a shareholder to request an extraordinary meeting of shareholders is less than or equal to $10 \%$ of outstanding capital shares. The index ranges from 0 to 5 , where 0 signifies the weakest investor protections and 5 signifies the strongest investor protections. Source: La Porta et al. (1997).

Legal Origin $\quad$ An indicator variable that signifies the legal origin of the country’s Company Law or Commercial Code. Legal origin may be English common law, French civil law, German civil law or Scandinavian civil law. Source: La Porta et al. (1998).

Disclosure The Disclosure index equals the arithmetic average of 6 separate indices of information that firms are legally required to include in their prospectuses: (1) Compensation; (2) Shareholders; (3) Inside Ownership; (4) Irregular contracts; (5) Transactions. 
directors and key officers. Equals one if the law or the listing rules require that the compensation of each director and key officer be reported in the prospectus of a newly-listed firm; equals one-half if only the aggregate compensation of directors and key officers must be reported in the prospectus of a newly-listed firm; equals zero when there is no requirement to disclose the compensation of directors and key officers in the prospectus for a newly-listed firm.”

(2) Shareholders is “[a]n index of disclosure requirements regarding the Issuer's equity ownership structure. Equals one if the law or the listing rules require disclosing the name and ownership stake of each shareholder who, directly or indirectly, controls ten percent or more of the Issuer's voting securities; equals one-half if reporting requirements for the Issuer's $10 \%$ shareholders do not include indirect ownership or if only their aggregate ownership needs to be disclosed; equals zero when the law does not require disclosing the name and ownership stake of the Issuer's $10 \%$ shareholders. No distinction is drawn between large-shareholder reporting requirements imposed on firms and those imposed on large shareholders themselves."

(3) Inside Ownership is "[a]n index of prospectus disclosure requirements regarding the equity ownership of the Issuer's shares by its directors and key officers. Equals one if the law or the listing rules require that the ownership of the Issuer's shares by each of its directors and key officers be disclosed in the prospectus; equals one-half if only the aggregate number of the Issuer's shares owned by its directors and key officers must be disclosed in the prospectus; equals zero when the ownership of Issuer's shares by its directors and key officers need not be disclosed in the prospectus.”

(4) Irregular contracts is “[a]n index of prospectus disclosure requirements regarding the Issuer's contracts outside the ordinary course of business. Equals one if the law or the listing rules require that the terms of material contracts made by the Issuer outside the ordinary course of its business be disclosed in the prospectus; equals one-half if the terms of only some material contracts made outside the ordinary course of business must be disclosed; equals zero otherwise.”

(5) Transactions is "[a]n index of the prospectus disclosure requirements regarding transactions between the Issuer and its directors, officers, and/or large shareholders (i.e., "related parties”). Equals one if the law or the listing rules require that all transactions in which related parties have, or will have, an interest be disclosed in the prospectus; equals one-half if only some transactions between the Issuer and related parties must be disclosed in the prospectus; equals zero if transactions between the Issuer and related parties need not be disclosed in the prospectus.”

Source: La Porta et al. (2003)

Accounting

The accounting index is a measure of the quality of accounting standards. The accounting index assigns a rating to companies' 1990 annual reports on the basis of their inclusion or exclusion of 90 items. The 90 items are divided into 7 categories (general information, income statements, balance sheets, funds flow statement, accounting standards, stock data and special items). For each country, the index is based on examination of a minimum of 3 companies. The companies represent a cross-section of various industries. Seventy percent are industrial companies, while the remaining thirty percent are financial companies. Source: La Porta et al. (1998). 


\section{Table 2: Formal Insider Trading Law and Enforceability}

This table presents the formal insider trading law and enforcement measures for the sample countries, grouped by legal origin. The columns contain the following variables: (1) Scope equals the sum of Tipping and Tippee; (2) Sanction equals the sum of Damages and Criminal; (3) the aggregate IT Law index is the sum of Scope and Sanction; (4) Enforced by 1994 equals one if the insider trading prohibition was enforced by 1994, and zero otherwise; (5) Public Enforcement Power is the mean of the indices of the securities market supervisor's characteristics and investigative powers; and (6) Private Enforcement Power is the product of Private Right and the efficiency of the judiciary. All variables are described in detail in Table 1 . The superscripts a and c denote statistical significance at the $1 \%$ and $10 \%$ levels, respectively. N/A means data are not available. 
Table 2 - Continued

\begin{tabular}{|c|c|c|c|c|c|c|}
\hline & Scope & Sanction & IT Law & $\begin{array}{l}\text { Enforced } \\
\text { by } 1994\end{array}$ & $\begin{array}{c}\text { Public } \\
\text { Enforcement } \\
\text { Power }\end{array}$ & $\begin{array}{l}\text { Private } \\
\text { Enforcement } \\
\text { Power }\end{array}$ \\
\hline & (1) & (2) & (3) & (4) & (5) & (6) \\
\hline \multicolumn{7}{|l|}{ Common Law } \\
\hline Australia & 2.00 & 1.00 & 3.00 & 0 & 0.88 & 10.00 \\
\hline Canada & 2.00 & 2.00 & 4.00 & 1 & 0.81 & 9.25 \\
\hline Hong Kong & 2.00 & 1.00 & 3.00 & 1 & 0.75 & 0.00 \\
\hline India & 1.00 & 1.00 & 2.00 & 0 & 0.69 & 0.00 \\
\hline Ireland & 2.00 & 1.00 & 3.00 & 0 & 0.13 & 8.75 \\
\hline Malaysia & 1.00 & 1.00 & 2.00 & 0 & 0.69 & 9.00 \\
\hline Singapore & 2.00 & 1.00 & 3.00 & 1 & 0.75 & 10.00 \\
\hline South Africa & 1.00 & 1.00 & 2.00 & 0 & 0.38 & 6.00 \\
\hline Thailand & 2.00 & 1.00 & 3.00 & 1 & 0.88 & 0.00 \\
\hline UK & 2.00 & 1.00 & 3.00 & 1 & 0.63 & 0.00 \\
\hline USA & 2.00 & 2.00 & 4.00 & 1 & 1.00 & 10.00 \\
\hline $\begin{array}{l}\text { Common Law Average } \\
\text { French Civil Law }\end{array}$ & 1.73 & 1.18 & 2.91 & 0.54 & 0.69 & 5.73 \\
\hline Belgium & 2.00 & 1.00 & 3.00 & 1 & 0.13 & 0.00 \\
\hline Brazil & 2.00 & 0.00 & 2.00 & 1 & 0.50 & 5.75 \\
\hline France & 2.00 & 2.00 & 4.00 & 1 & 0.94 & 0.00 \\
\hline Greece & 2.00 & 0.00 & 2.00 & 0 & 0.38 & 0.00 \\
\hline Indonesia & 1.00 & 1.00 & 2.00 & 0 & 0.75 & 0.00 \\
\hline Italy & 2.00 & 1.00 & 3.00 & 0 & 0.50 & 0.00 \\
\hline Mexico & 1.00 & 0.00 & 1.00 & 0 & 0.25 & 0.00 \\
\hline Netherlands & 2.00 & 1.00 & 3.00 & 1 & 0.50 & 0.00 \\
\hline Philippines & 1.00 & 1.00 & 2.00 & 0 & 0.88 & 0.00 \\
\hline Portugal & 2.00 & 1.00 & 3.00 & 0 & 0.88 & 5.50 \\
\hline Spain & 2.00 & 1.00 & 3.00 & 0 & 0.50 & 6.25 \\
\hline $\begin{array}{c}\text { French Civil Law Average } \\
\text { German Civil Law }\end{array}$ & 1.73 & 0.82 & 2.55 & 0.36 & 0.56 & 1.59 \\
\hline Austria & 2.00 & 0.00 & 2.00 & 0 & 0.13 & 0.00 \\
\hline Germany & 2.00 & 1.00 & 3.00 & 0 & 0.25 & 0.00 \\
\hline Japan & 1.00 & 1.00 & 2.00 & 1 & 0.00 & 0.00 \\
\hline Luxembourg & 2.00 & 1.00 & 3.00 & 0 & N/A & N/A \\
\hline South Korea & 2.00 & 2.00 & 4.00 & 1 & 0.38 & 6.00 \\
\hline Switzerland & 2.00 & 1.00 & 3.00 & 0 & 0.25 & 0.00 \\
\hline Taiwan & 2.00 & 1.00 & 3.00 & 1 & 0.38 & 6.75 \\
\hline $\begin{array}{l}\text { German Civil Law Average } \\
\text { Scandinavian Civil Law }\end{array}$ & 1.86 & 1.00 & 2.86 & 0.43 & 0.23 & 2.13 \\
\hline Denmark & 2.00 & 1.00 & 3.00 & 0 & 0.38 & 0.00 \\
\hline Finland & 2.00 & 1.00 & 3.00 & 1 & 0.38 & 0.00 \\
\hline Norway & 1.00 & 0.00 & 1.00 & 1 & 0.13 & 0.00 \\
\hline Sweden & 2.00 & 1.00 & 3.00 & 1 & 0.25 & 0.00 \\
\hline $\begin{array}{c}\text { Scandinavian Civil Law } \\
\text { Average }\end{array}$ & 1.75 & 0.75 & 2.50 & 0.75 & 0.28 & 0.00 \\
\hline Civil Law Average & 1.77 & 0.86 & 2.64 & 0.45 & 0.41 & 1.44 \\
\hline
\end{tabular}




\begin{tabular}{ccccccc}
\hline & Scope & Sanction & IT Law & $\begin{array}{c}\text { Enforced } \\
\text { by } 1994\end{array}$ & $\begin{array}{c}\text { Public } \\
\text { Enforcement } \\
\text { Power }\end{array}$ & $\begin{array}{c}\text { Private } \\
\text { Enforcement } \\
\text { Power }\end{array}$ \\
& $(1)$ & $(2)$ & $(3)$ & $(4)$ & $(5)$ & 2.91 \\
\hline Overall Average & 1.76 & 0.97 & 2.73 & 0.48 & 0.51 & \\
$\begin{array}{l}\text { t-test of difference in means } \\
\text { (common law vs. civil law) }\end{array}$ & -0.28 & $1.67^{\mathrm{c}}$ & 0.97 & 0.48 & $2.86^{\mathrm{a}}$ & $3.33^{\mathrm{a}}$ \\
\hline
\end{tabular}




\section{Table 3: Correlation Matrix}

This table presents pairwise correlation coefficients for the dependent variables, the substantive insider trading law measures and the enforcement measures. All variables are described in detail in Table 1. The numbers in parentheses are the probability levels (p-values) at which the null hypothesis of zero correlation can be rejected in two-tailed tests. The superscripts a, b, and c denote statistical significance at the $1 \%, 5 \%$, and $10 \%$ levels, respectively. 
Table 3 -Continued

\begin{tabular}{|c|c|c|c|c|c|c|c|c|c|}
\hline & $\begin{array}{c}\text { (1) } \\
\text { Own'shp } \\
\text { Dispersion }\end{array}$ & $\begin{array}{c}(2) \\
\text { Stock Price Synchr. }\end{array}$ & $\begin{array}{c}(3) \\
\text { Stock Mkt. } \\
\text { Turn. }\end{array}$ & $\begin{array}{c}\text { (4) } \\
\text { Scope }\end{array}$ & $\begin{array}{c}\text { (5) } \\
\text { Sanction }\end{array}$ & $\begin{array}{c}(6) \\
\text { IT Law }\end{array}$ & $\begin{array}{c}\text { (7) } \\
\text { Enf. By } 1994\end{array}$ & $\begin{array}{c}\text { (8) } \\
\text { Pub. Enf. }\end{array}$ & $\begin{array}{c}\text { (9) } \\
\text { Priv. Enf. }\end{array}$ \\
\hline \multicolumn{10}{|l|}{ Dependent Variables } \\
\hline (1) Ownership Dispersion & 1.00 & & & & & & & & \\
\hline (2) Stock Price Synchronicity & $\begin{array}{l}-0.19 \\
(0.31)\end{array}$ & 1.00 & & & & & & & \\
\hline (3) Stock Market Turnover & $\begin{array}{l}0.39^{\mathrm{b}} \\
(0.03)\end{array}$ & $\begin{array}{l}-0.15 \\
(0.42)\end{array}$ & 1.00 & & & & & & \\
\hline \multicolumn{10}{|l|}{ Insider Trading Law Measures } \\
\hline (4) Scope & $\begin{array}{c}0.13 \\
(0.47)\end{array}$ & $\begin{array}{l}-0.39^{\mathrm{b}} \\
(0.03)\end{array}$ & $\begin{array}{l}0.36^{\mathrm{b}} \\
(0.04)\end{array}$ & 1.00 & & & & & \\
\hline (5) Sanction & $\begin{array}{l}0.53^{\mathrm{a}} \\
(0.00)\end{array}$ & $\begin{array}{l}-0.37^{\mathrm{b}} \\
(0.04)\end{array}$ & $\begin{array}{c}0.24 \\
(0.18)\end{array}$ & $\begin{array}{c}0.24 \\
(0.18)\end{array}$ & 1.00 & & & & \\
\hline (6) IT Law & $\begin{array}{l}0.44^{\mathrm{a}} \\
(0.01)\end{array}$ & $\begin{array}{l}-0.48^{\mathrm{a}} \\
(0.01)\end{array}$ & $\begin{array}{l}0.37^{\mathrm{b}} \\
(0.03)\end{array}$ & $\begin{array}{c}0.74^{\mathrm{a}} \\
(0.00)\end{array}$ & $\begin{array}{c}0.83^{\mathrm{a}} \\
(0.00)\end{array}$ & 1.00 & & & \\
\hline \multicolumn{10}{|l|}{ Enforcement Measures } \\
\hline (7) Enforced by 1994 & $\begin{array}{l}0.52^{\mathrm{a}} \\
(0.00)\end{array}$ & $\begin{array}{l}-0.11 \\
(0.55)\end{array}$ & $\begin{array}{c}0.24 \\
(0.18)\end{array}$ & $\begin{array}{c}0.26 \\
(0.13)\end{array}$ & $\begin{array}{c}0.29^{c} \\
(0.10)\end{array}$ & $\begin{array}{l}0.35^{\mathrm{b}} \\
(0.04)\end{array}$ & 1.00 & & \\
\hline (8) Public Enforcement Power & $\begin{array}{c}0.01 \\
(0.96)\end{array}$ & $\begin{array}{l}-0.28 \\
(0.13)\end{array}$ & $\begin{array}{l}-0.09 \\
(0.60)\end{array}$ & $\begin{array}{c}0.08 \\
(0.66)\end{array}$ & $\begin{array}{l}0.47^{\mathrm{a}} \\
(0.01)\end{array}$ & $\begin{array}{l}0.38^{\mathrm{b}} \\
(0.03)\end{array}$ & $\begin{array}{c}0.06 \\
(0.76)\end{array}$ & 1.00 & \\
\hline (9) Private Enforcement Power & $\begin{array}{c}0.19 \\
(0.28)\end{array}$ & $\begin{array}{l}-0.05 \\
(0.78)\end{array}$ & $\begin{array}{l}-0.01 \\
(0.96)\end{array}$ & $\begin{array}{c}0.15 \\
(0.40)\end{array}$ & $\begin{array}{c}0.34^{\mathrm{c}} \\
(0.06)\end{array}$ & $\begin{array}{l}0.32^{\mathrm{c}} \\
(0.07)\end{array}$ & $\begin{array}{c}0.02 \\
(0.92)\end{array}$ & $\begin{array}{l}0.33^{\mathrm{c}} \\
(0.07)\end{array}$ & 1.00 \\
\hline
\end{tabular}




\section{Table 4: Do Insider Trading Laws Matter?}

This table presents ordinary least squares regressions for the dependent variables: ownership dispersion (Panel A); stock price synchronicity (Panel B); and stock market turnover (Panel C). The independent variables include the insider trading law variables: Scope, Sanction, and IT Law. The control variables include: the alternative disclosure variables; anti-director rights (Panels A and B); legal origin dummy variables; the log of GDP per capita; and the growth of GDP per capita (in Panels B and C). All variables are described in detail in Table 1 . Robust standard errors are reported in parentheses. The superscripts a, b, and c denote statistical significance at the $1 \%, 5 \%$, and $10 \%$ levels, respectively. 
Table 4 - Continued

Panel A: Ownership Dispersion

\begin{tabular}{|c|c|c|c|c|c|c|c|c|c|}
\hline Independent Variable & $(1)$ & $(2)$ & (3) & (4) & (5) & (6) & $(7)$ & (8) & (9) \\
\hline Scope & $\begin{array}{c}-0.0066 \\
(0.0603)\end{array}$ & & & $\begin{array}{c}0.0274 \\
(0.0527)\end{array}$ & $\begin{array}{c}0.0220 \\
(0.0643)\end{array}$ & & & & \\
\hline Sanction & & $\begin{array}{c}0.1133^{\mathrm{a}} \\
(0.0287)\end{array}$ & & & & $\begin{array}{c}0.1080^{\mathrm{a}} \\
(0.0401)\end{array}$ & $\begin{array}{c}0.1050^{\mathrm{a}} \\
(0.0316)\end{array}$ & & \\
\hline IT Law (Scope + Sanction) & & & $\begin{array}{c}0.0642^{\mathrm{b}} \\
(0.0306)\end{array}$ & & & & & $\begin{array}{c}0.0520^{c} \\
(0.0281)\end{array}$ & $\begin{array}{c}0.0629^{b} \\
(0.0296)\end{array}$ \\
\hline Disclosure & & & & $\begin{array}{c}0.2800^{\mathrm{c}} \\
(0.1506)\end{array}$ & & $\begin{array}{c}0.0319 \\
(0.1503)\end{array}$ & & $\begin{array}{c}0.1866 \\
(0.1412)\end{array}$ & \\
\hline Accounting & & & & & $\begin{array}{c}0.0044 \\
(0.0034)\end{array}$ & & $\begin{array}{c}0.0026 \\
(0.0026)\end{array}$ & & $\begin{array}{c}0.0041 \\
(0.0028)\end{array}$ \\
\hline Anti-Director Rights & $\begin{array}{c}0.0397^{\mathrm{b}} \\
(0.0187)\end{array}$ & $\begin{array}{c}0.0291 \\
(0.0182)\end{array}$ & $\begin{array}{c}0.0371^{\mathrm{c}} \\
(0.0196)\end{array}$ & $\begin{array}{c}0.0343 \\
(0.0210)\end{array}$ & $\begin{array}{c}0.0392^{\mathrm{C}} \\
(0.0219)\end{array}$ & $\begin{array}{c}0.0288 \\
(0.0182)\end{array}$ & $\begin{array}{c}0.0295 \\
(0.0207)\end{array}$ & $\begin{array}{c}0.0329 \\
(0.0197)\end{array}$ & $\begin{array}{c}0.0358 \\
(0.0223)\end{array}$ \\
\hline French Civil Law & $\begin{array}{c}-0.0474 \\
(0.0612)\end{array}$ & $\begin{array}{c}-0.0279 \\
(0.0539)\end{array}$ & $\begin{array}{c}-0.0321 \\
(0.0555)\end{array}$ & $\begin{array}{c}0.0414 \\
(0.0919)\end{array}$ & $\begin{array}{c}-0.0021 \\
(0.0936)\end{array}$ & $\begin{array}{c}-0.0190 \\
(0.0810)\end{array}$ & $\begin{array}{c}0.0012 \\
(0.0819)\end{array}$ & $\begin{array}{c}0.0228 \\
(0.0858)\end{array}$ & $\begin{array}{c}0.0106 \\
(0.0865)\end{array}$ \\
\hline German Civil Law & $\begin{array}{c}0.0663 \\
(0.0963)\end{array}$ & $\begin{array}{c}0.0814 \\
(0.0717)\end{array}$ & $\begin{array}{c}0.0962 \\
(0.0823)\end{array}$ & $\begin{array}{c}0.1471 \\
(0.0961)\end{array}$ & $\begin{array}{c}0.1187 \\
(0.1084)\end{array}$ & $\begin{array}{c}0.0888 \\
(0.0902)\end{array}$ & $\begin{array}{c}0.1115 \\
(0.0891)\end{array}$ & $\begin{array}{c}0.1375 \\
(0.0927)\end{array}$ & $\begin{array}{c}0.1386 \\
(0.0973)\end{array}$ \\
\hline Scandinavian Civil Law & $\begin{array}{c}0.0476 \\
(0.0693)\end{array}$ & $\begin{array}{c}0.0995 \\
(0.0692)\end{array}$ & $\begin{array}{c}0.1005 \\
(0.0712)\end{array}$ & $\begin{array}{c}0.1353 \\
(0.0944)\end{array}$ & $\begin{array}{c}0.0505 \\
(0.0656)\end{array}$ & $\begin{array}{l}0.1058 \\
0.0803\end{array}$ & $\begin{array}{c}0.0966 \\
(0.0735)\end{array}$ & $\begin{array}{c}0.1414 \\
(0.0848)\end{array}$ & $\begin{array}{c}0.0956 \\
(0.0697)\end{array}$ \\
\hline Log of GDP Per Capita & $\begin{array}{c}0.0262 \\
(0.0275)\end{array}$ & $\begin{array}{c}0.0141 \\
(0.0182)\end{array}$ & $\begin{array}{c}0.0012 \\
(0.0231)\end{array}$ & $\begin{array}{c}0.0214 \\
(0.0262)\end{array}$ & $\begin{array}{c}0.0138 \\
(0.0345)\end{array}$ & $\begin{array}{c}0.0151 \\
(0.0193)\end{array}$ & $\begin{array}{c}0.0111 \\
(0.0257)\end{array}$ & $\begin{array}{c}0.0086 \\
(0.0245)\end{array}$ & $\begin{array}{c}-0.0036 \\
(0.0305)\end{array}$ \\
\hline Constant & $\begin{array}{c}0.2295 \\
(0.2337)\end{array}$ & $\begin{array}{c}0.2323 \\
(0.1805)\end{array}$ & $\begin{array}{c}0.2692 \\
(0.2036)\end{array}$ & $\begin{array}{c}-0.0125 \\
(0.2519)\end{array}$ & $\begin{array}{c}-0.0200 \\
(0.3673)\end{array}$ & $\begin{array}{c}0.2026 \\
(0.2444)\end{array}$ & $\begin{array}{c}0.0783 \\
(0.2946)\end{array}$ & $\begin{array}{c}0.0882 \\
(0.2544)\end{array}$ & $\begin{array}{c}0.0290 \\
(0.3268)\end{array}$ \\
\hline Number of Observations & 31 & 31 & 31 & 31 & 29 & 31 & 29 & 31 & 29 \\
\hline $\mathrm{R}^{2}$ & 0.39 & 0.57 & 0.49 & 0.47 & 0.45 & 0.57 & 0.59 & 0.53 & 0.54 \\
\hline
\end{tabular}


Table 4-Continued

Panel B: Stock Price Synchronicity

\begin{tabular}{|c|c|c|c|c|c|c|c|c|c|}
\hline Independent Variable & $(1)$ & $(2)$ & (3) & $(4)$ & $(5)$ & $(6)$ & (7) & (8) & (9) \\
\hline Scope & $\begin{array}{l}-2.9072^{b} \\
(1.3337)\end{array}$ & & & $\begin{array}{l}-2.7789^{c} \\
(1.4712)\end{array}$ & $\begin{array}{c}-2.3176^{\mathrm{C}} \\
1.1417\end{array}$ & & & & \\
\hline Sanction & & $\begin{array}{l}-2.5627^{\mathrm{a}} \\
(0.9722)\end{array}$ & & & & $\begin{array}{l}-4.8846^{\mathrm{a}} \\
(1.3810)\end{array}$ & $\begin{array}{l}-3.1257^{\mathrm{a}} \\
(1.0273)\end{array}$ & & \\
\hline $\begin{array}{l}\text { IT Law (Scope + } \\
\text { Sanction) }\end{array}$ & & & $\begin{array}{l}-2.2440^{b} \\
(0.8791)\end{array}$ & & & & & $\begin{array}{l}-2.6985^{\mathrm{a}} \\
(1.0177)\end{array}$ & $\begin{array}{l}-2.2516^{\mathrm{b}} \\
(0.8473)\end{array}$ \\
\hline Disclosure & & & & $\begin{array}{c}1.0351 \\
(4.7464)\end{array}$ & & $\begin{array}{l}13.7033^{\mathrm{a}} \\
(4.4974)\end{array}$ & & $\begin{array}{c}6.9757^{c} \\
(3.8257)\end{array}$ & \\
\hline Accounting & & & & & $\begin{array}{c}0.1535^{\mathrm{b}} \\
(0.0693)\end{array}$ & & $\begin{array}{c}0.2374^{\mathrm{a}} \\
(0.0637)\end{array}$ & & $\begin{array}{c}0.1912^{\mathrm{a}} \\
(0.0569)\end{array}$ \\
\hline Anti-Director Rights & $\begin{array}{l}-1.4169^{b} \\
(0.6276)\end{array}$ & $\begin{array}{c}-1.0140 \\
(0.6766)\end{array}$ & $\begin{array}{l}-1.1550^{\mathrm{C}} \\
(0.6274)\end{array}$ & $\begin{array}{l}-1.4423^{b} \\
(0.6059)\end{array}$ & $\begin{array}{l}-1.3121^{b} \\
(0.4951)\end{array}$ & $\begin{array}{l}-1.1947^{b} \\
(0.4756)\end{array}$ & $\begin{array}{l}-0.9485^{c} \\
(0.5499)\end{array}$ & $\begin{array}{l}-1.3435^{b} \\
(0.5172)\end{array}$ & $\begin{array}{l}-1.1133^{b} \\
(0.4960)\end{array}$ \\
\hline French Civil Law & $\begin{array}{c}-1.8504 \\
(2.3225)\end{array}$ & $\begin{array}{c}-1.8928 \\
(2.3607)\end{array}$ & $\begin{array}{l}-1.9994 \\
(2.2342)\end{array}$ & $\begin{array}{l}-1.5354 \\
(2.7316)\end{array}$ & $\begin{array}{c}1.0979 \\
(2.5937)\end{array}$ & $\begin{array}{c}1.9808 \\
(2.0350)\end{array}$ & $\begin{array}{c}1.7161 \\
(2.2893)\end{array}$ & $\begin{array}{c}0.0065 \\
(2.2036)\end{array}$ & $\begin{array}{c}1.2164 \\
(2.2868)\end{array}$ \\
\hline German Civil Law & $\begin{array}{c}-1.1424 \\
(2.4054)\end{array}$ & $\begin{array}{c}-0.5711 \\
(2.5948)\end{array}$ & $\begin{array}{c}-1.2541 \\
(2.5676)\end{array}$ & $\begin{array}{l}-0.8182 \\
(2.6502)\end{array}$ & $\begin{array}{c}1.4428 \\
(2.2462)\end{array}$ & $\begin{array}{c}2.8303 \\
(1.9207)\end{array}$ & $\begin{array}{c}2.5268 \\
(2.1789)\end{array}$ & $\begin{array}{c}0.4358 \\
(2.2997)\end{array}$ & $\begin{array}{c}1.4642 \\
(2.2157)\end{array}$ \\
\hline Scandinavian Civil Law & $\begin{array}{c}0.9137 \\
(2.1509)\end{array}$ & $\begin{array}{c}0.9764 \\
(2.0989)\end{array}$ & $\begin{array}{c}0.3177 \\
(2.3164)\end{array}$ & $\begin{array}{c}1.2276 \\
(2.3001)\end{array}$ & $\begin{array}{c}1.9887 \\
(2.2241)\end{array}$ & $\begin{array}{c}3.6915 \\
(2.1827)\end{array}$ & $\begin{array}{c}1.3965 \\
(2.2755)\end{array}$ & $\begin{array}{c}1.8103 \\
(2.3181)\end{array}$ & $\begin{array}{c}1.0464 \\
(2.3922)\end{array}$ \\
\hline Log of GDP Per Capita & $\begin{array}{c}-0.7256 \\
(0.6923)\end{array}$ & $\begin{array}{l}-1.2102^{\mathrm{c}} \\
(0.6466)\end{array}$ & $\begin{array}{l}-0.6407 \\
(0.7093)\end{array}$ & $\begin{array}{l}-0.7428 \\
(0.7012)\end{array}$ & $\begin{array}{l}-1.4517^{\mathrm{a}} \\
(0.5131)\end{array}$ & $\begin{array}{c}-0.7041 \\
(0.4481)\end{array}$ & $\begin{array}{l}-1.7965^{\mathrm{a}} \\
(0.4613)\end{array}$ & $\begin{array}{l}-0.3458 \\
(0.6428)\end{array}$ & $\begin{array}{l}-1.2364^{b} \\
(0.5447)\end{array}$ \\
\hline Growth of GDP Per Capita & $\begin{array}{c}0.4739 \\
(0.3892)\end{array}$ & $\begin{array}{c}0.5822 \\
(0.4151)\end{array}$ & $\begin{array}{c}0.5696 \\
(0.4163)\end{array}$ & $\begin{array}{c}0.4720 \\
(0.3895)\end{array}$ & $\begin{array}{c}0.6693^{\mathrm{C}} \\
(0.3674)\end{array}$ & $\begin{array}{c}0.6578^{b} \\
(0.3005)\end{array}$ & $\begin{array}{c}0.8159^{b} \\
(0.3411)\end{array}$ & $\begin{array}{c}0.5771 \\
(0.3483)\end{array}$ & $\begin{array}{c}.7700^{\mathrm{b}} \\
(0.3558)\end{array}$ \\
\hline Constant & $\begin{array}{l}80.2186^{\mathrm{a}} \\
(6.9145)\end{array}$ & $\begin{array}{l}80.7139^{a} \\
(6.2473)\end{array}$ & $\begin{array}{l}79.5747^{\mathrm{a}} \\
(6.1285)\end{array}$ & $\begin{array}{l}79.3425^{a} \\
(8.1925)\end{array}$ & $\begin{array}{c}73.495^{\mathrm{a}} \\
(7.6710)\end{array}$ & $\begin{array}{l}67.0850^{\mathrm{a}} \\
(5.9803)\end{array}$ & $\begin{array}{l}68.4562^{\mathrm{a}} \\
(4.3487)\end{array}$ & $\begin{array}{l}72.7086^{a} \\
(6.5650)\end{array}$ & $\begin{array}{l}70.2672^{\mathrm{a}} \\
\text { (4.9611) }\end{array}$ \\
\hline Number of Observations & 30 & 30 & 30 & 30 & 28 & 30 & 28 & 30 & 28 \\
\hline $\mathrm{R}^{2}$ & 0.46 & 0.51 & 0.54 & 0.47 & 0.56 & 0.65 & 0.67 & 0.60 & 0.67 \\
\hline
\end{tabular}


Table 4 - Continued

Panel C: Stock Market Turnover

\begin{tabular}{|c|c|c|c|c|c|c|c|c|c|}
\hline Independent Variable & $(1)$ & $(2)$ & (3) & $(4)$ & (5) & (6) & $(7)$ & (8) & (9) \\
\hline Scope & $\begin{array}{c}26.9504 \\
(18.5936)\end{array}$ & & & $\begin{array}{l}31.0102 \\
(18.888)\end{array}$ & $\begin{array}{c}35.2977^{\mathrm{C}} \\
(19.9048)\end{array}$ & & & & \\
\hline Sanction & & $\begin{array}{l}20.5811^{\mathrm{c}} \\
(11.7673)\end{array}$ & & & & $\begin{array}{c}30.8760^{\mathrm{C}} \\
(18.0758)\end{array}$ & $\begin{array}{l}19.1473^{42} \\
(11.4564)\end{array}$ & & \\
\hline $\begin{array}{l}\text { IT Law (Scope + } \\
\text { Sanction) }\end{array}$ & & & $\begin{array}{c}19.4157^{c} \\
(10.2335)\end{array}$ & & & & & $\begin{array}{l}20.9316^{c} \\
(12.0507)\end{array}$ & $\begin{array}{c}19.2353^{c} \\
(10.2337)\end{array}$ \\
\hline Disclosure & & & & $\begin{array}{r}31.3557 \\
(56.0299)\end{array}$ & & $\begin{array}{l}-58.8215 \\
(71.0572)\end{array}$ & & $\begin{array}{l}-21.8199 \\
(57.3087)\end{array}$ & \\
\hline Accounting & & & & & $\begin{array}{l}1.4338^{\mathrm{c}} \\
(0.7110)\end{array}$ & & $\begin{array}{c}0.6226 \\
(0.5429)\end{array}$ & & $\begin{array}{c}0.8900^{\mathrm{c}} \\
(0.5954)\end{array}$ \\
\hline French Civil Law & $\begin{array}{c}-1.3613 \\
(14.1303)\end{array}$ & $\begin{array}{c}5.3716 \\
(14.1536)\end{array}$ & $\begin{array}{c}4.4471 \\
(13.3826)\end{array}$ & $\begin{array}{c}9.8757 \\
(29.6645)\end{array}$ & $\begin{array}{c}16.4909 \\
(21.6796)\end{array}$ & $\begin{array}{l}-12.9811 \\
(28.4249)\end{array}$ & $\begin{array}{c}14.4556 \\
(19.3081)\end{array}$ & $\begin{array}{c}-3.0687 \\
(27.3983)\end{array}$ & $\begin{array}{c}16.9328 \\
(19.2896)\end{array}$ \\
\hline German Civil Law & $\begin{array}{r}49.6448^{\mathrm{c}} \\
(28.5899)\end{array}$ & $\begin{array}{c}49.4565 \\
(29.9006)\end{array}$ & $\begin{array}{l}53.5676^{c} \\
(27.8088)\end{array}$ & $\begin{array}{l}59.8128^{\mathrm{b}} \\
(25.2840)\end{array}$ & $\begin{array}{l}67.8067^{\mathrm{b}} \\
(28.9938)\end{array}$ & $\begin{array}{c}35.1233 \\
(27.8449)\end{array}$ & $\begin{array}{l}57.6334^{c} \\
(31.3980)\end{array}$ & $\begin{array}{l}47.9280^{c} \\
(25.0427)\end{array}$ & $\begin{array}{l}64.7721^{\mathrm{b}} \\
(29.4608)\end{array}$ \\
\hline Scandinavian Civil Law & $\begin{array}{c}-0.5551 \\
(13.2938)\end{array}$ & $\begin{array}{c}1.4722 \\
(10.7969)\end{array}$ & $\begin{array}{c}6.6676 \\
(13.4714)\end{array}$ & $\begin{array}{r}10.1154 \\
(19.7240)\end{array}$ & $\begin{array}{c}2.4975 \\
(16.0194)\end{array}$ & $\begin{array}{l}-11.2689 \\
(22.7186)\end{array}$ & $\begin{array}{c}2.7876 \\
(11.5944)\end{array}$ & $\begin{array}{c}1.2692 \\
(20.6916)\end{array}$ & $\begin{array}{c}8.2764 \\
(14.6858)\end{array}$ \\
\hline Log of GDP Per Capita & $\begin{array}{c}2.7778 \\
(7.7347)\end{array}$ & $\begin{array}{l}7.5848^{\mathrm{b}} \\
(3.7151)\end{array}$ & $\begin{array}{c}2.4953 \\
(5.0229)\end{array}$ & $\begin{array}{c}2.2211 \\
(7.4208)\end{array}$ & $\begin{array}{l}-1.7813 \\
(7.3606)\end{array}$ & $\begin{array}{c}5.3526 \\
(5.1774)\end{array}$ & $\begin{array}{c}6.2407 \\
(4.0969)\end{array}$ & $\begin{array}{c}1.5332 \\
(6.6947)\end{array}$ & $\begin{array}{c}0.7248 \\
(5.5466)\end{array}$ \\
\hline $\begin{array}{l}\text { Growth of GDP Per } \\
\text { Capita }\end{array}$ & $\begin{array}{l}-2.0513 \\
(2.1903)\end{array}$ & $\begin{array}{l}-2.8561 \\
(2.3470)\end{array}$ & $\begin{array}{l}-2.7947 \\
(2.3433)\end{array}$ & $\begin{array}{l}-1.9669 \\
(2.4136)\end{array}$ & $\begin{array}{l}-1.3550 \\
(2.5925)\end{array}$ & $\begin{array}{c}-3.3982 \\
(2.6060)\end{array}$ & $\begin{array}{r}-2.3811 \\
(2.7061)\end{array}$ & $\begin{array}{l}-2.9070 \\
(2.4482)\end{array}$ & $\begin{array}{l}-2.2630 \\
(2.7800)\end{array}$ \\
\hline Constant & $\begin{array}{l}-17.7795 \\
(52.8786)\end{array}$ & $\begin{array}{l}-35.6633 \\
(44.3976)\end{array}$ & $\begin{array}{l}-21.6623 \\
(43.6627)\end{array}$ & $\begin{array}{l}-47.6604 \\
(97.4333)\end{array}$ & $\begin{array}{l}-96.2524 \\
(73.398)\end{array}$ & $\begin{array}{l}26.7628 \\
(100.02)\end{array}$ & $\begin{array}{l}-69.2798 \\
(61.0779)\end{array}$ & $\begin{array}{c}2.4070 \\
(95.4537)\end{array}$ & $\begin{array}{l}-71.7266 \\
(63.6001)\end{array}$ \\
\hline $\begin{array}{l}\text { Number of } \\
\text { Observations }\end{array}$ & 31 & 31 & 31 & 31 & 29 & 31 & 29 & 31 & 29 \\
\hline $\mathrm{R}^{2}$ & 0.40 & 0.41 & 0.44 & 0.41 & 0.44 & 0.44 & 0.41 & 0.45 & 0.46 \\
\hline
\end{tabular}

$42 \quad p$-value of $10.9 \%$. 


\section{Table 5: Taking Enforceability into Account}

This table presents ordinary least squares regressions for the dependent variables: ownership dispersion (Panel A); stock price synchronicity (Panel B); and stock market turnover (Panel C). The independent variables include the insider trading law variables: Scope, Sanction, and IT Law. The control variables include: the actual and potential enforcement variables; antidirector rights (Panels A and B); legal origin dummy variables; the log of GDP per capita; and the growth of GDP per capita (in Panels B and C). All variables are described in detail in Table 1. Robust standard errors are reported in parentheses. The superscripts a, b, and c denote statistical significance at the 1\%, 5\%, and $10 \%$ levels, respectively. 
Table 5 - Continued

Panel A: Ownership Dispersion

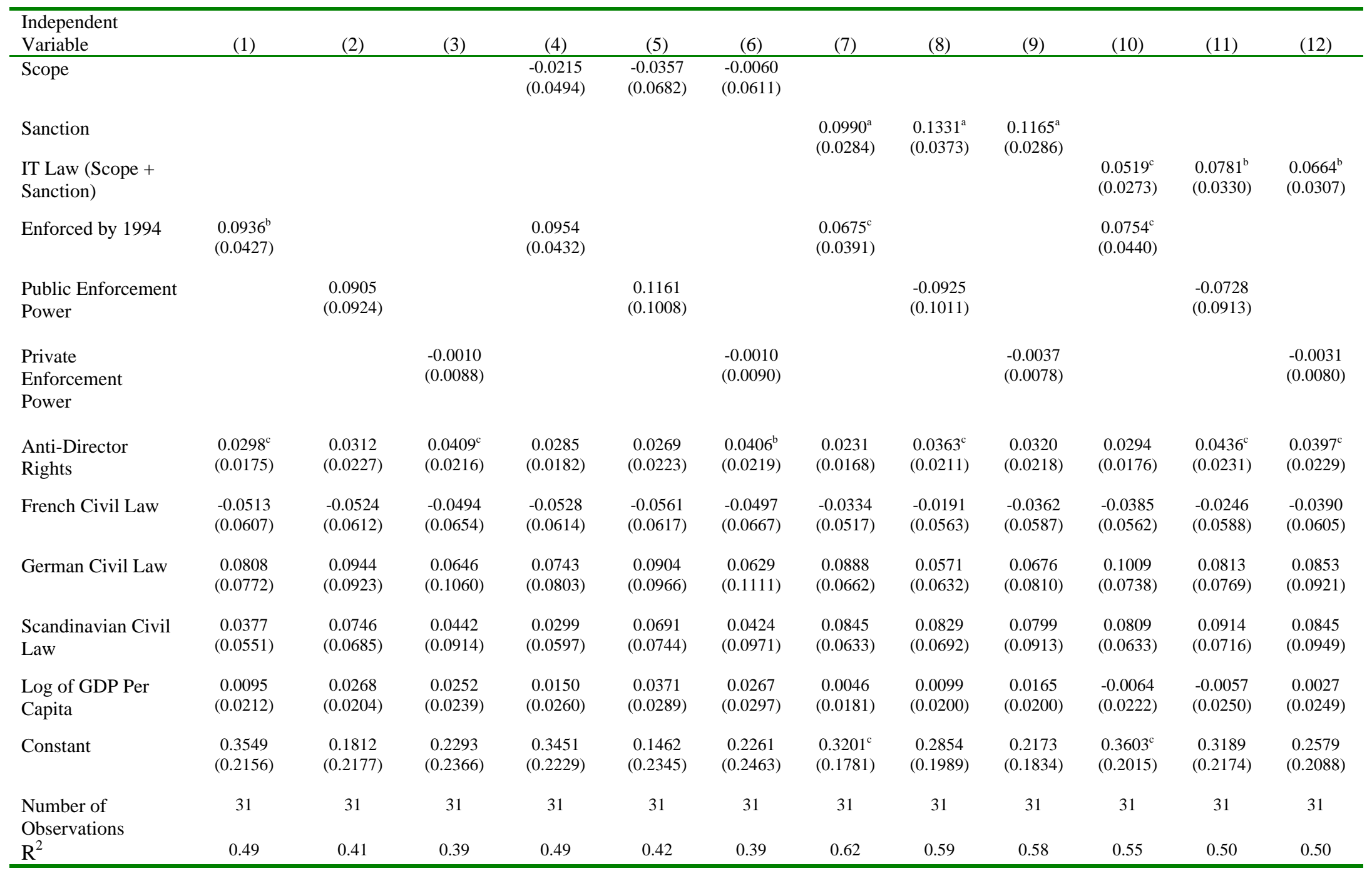


Table 5 - Continued

Panel B: Stock Price Synchronicity

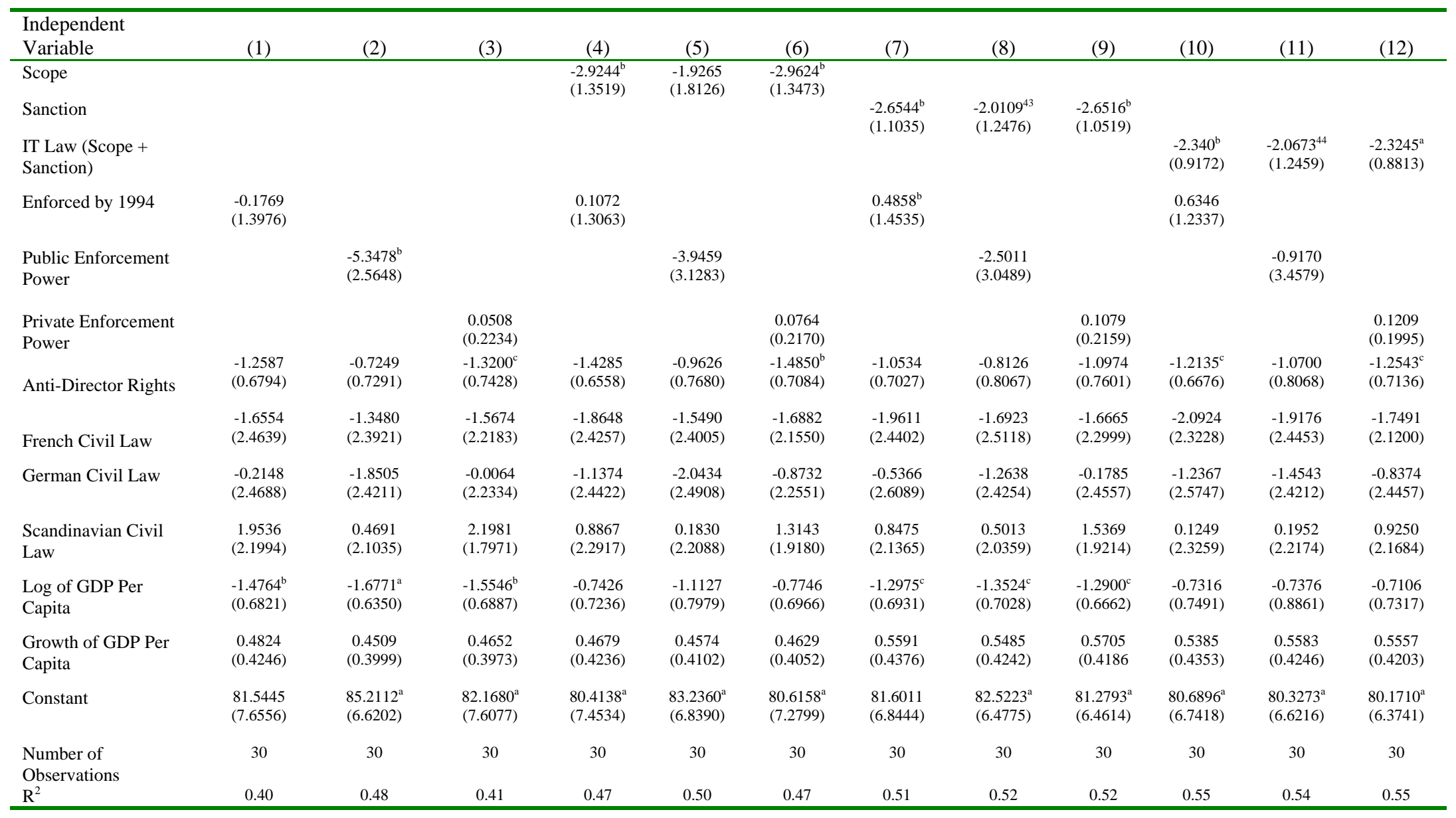

Table 5 - Continued

$43 \quad p$-value of $12.2 \%$.

$44 \quad p$-value of $11.2 \%$. 
Panel C: Stock Market Turnover

\begin{tabular}{|c|c|c|c|c|c|c|c|c|c|c|c|c|}
\hline $\begin{array}{l}\text { Independent } \\
\text { Variable }\end{array}$ & (1) & (2) & (3) & (4) & (5) & (6) & (7) & (8) & (9) & (10) & (11) & (12) \\
\hline Scope & & & & $\begin{array}{c}26.1177 \\
(21.0829)\end{array}$ & $\begin{array}{c}17.2454 \\
(20.3102)\end{array}$ & $\begin{array}{c}27.2463 \\
(19.3509)\end{array}$ & & & & & & \\
\hline Sanction & & & & & & & $\begin{array}{l}19.7731^{45} \\
(12.1186)\end{array}$ & $\begin{array}{c}10.0731 \\
(11.5384)\end{array}$ & $\begin{array}{l}22.0245^{\mathrm{c}} \\
(12.7460)\end{array}$ & & & \\
\hline $\begin{array}{l}\text { IT Law (Scope + } \\
\text { Sanction) }\end{array}$ & & & & & & & & & & $\begin{array}{l}18.9793^{46} \\
(11.3750)\end{array}$ & $\begin{array}{c}12.9257 \\
(10.4570)\end{array}$ & $\begin{array}{l}20.42712^{\mathrm{c}} \\
(10.8154)\end{array}$ \\
\hline Enforced by 1994 & $\begin{array}{c}9.2013 \\
(14.0127)\end{array}$ & & & $\begin{array}{c}7.5422 \\
(14.1537)\end{array}$ & & & $\begin{array}{c}3.7740 \\
(14.2576)\end{array}$ & & & $\begin{array}{c}2.7863 \\
(14.4431)\end{array}$ & & \\
\hline $\begin{array}{l}\text { Public Enforcement } \\
\text { Power }\end{array}$ & & $\begin{array}{l}55.5603^{c} \\
(31.8653)\end{array}$ & & & $\begin{array}{c}47.0251 \\
(34.4179)\end{array}$ & & & $\begin{array}{c}42.1356 \\
(33.7340)\end{array}$ & & & $\begin{array}{c}31.9367 \\
(33.0583)\end{array}$ & \\
\hline $\begin{array}{l}\text { Private Enforcement } \\
\text { Power }\end{array}$ & & & $\begin{array}{l}-0.7277 \\
(1.4938)\end{array}$ & & & $\begin{array}{l}-0.8370 \\
(1.4719)\end{array}$ & & & $\begin{array}{l}-1.3313 \\
(1.6079)\end{array}$ & & & $\begin{array}{l}-1.3695 \\
(1.4571)\end{array}$ \\
\hline French Civil Law & $\begin{array}{c}-0.0486 \\
(13.5708)\end{array}$ & $\begin{array}{c}7.3559 \\
(15.2629)\end{array}$ & $\begin{array}{c}-3.2909 \\
(12.2868)\end{array}$ & $\begin{array}{c}-0.9308 \\
(14.4379)\end{array}$ & $\begin{array}{c}5.6188 \\
(16.4537)\end{array}$ & $\begin{array}{c}-4.5308 \\
(12.4419)\end{array}$ & $\begin{array}{c}5.3421 \\
(14.2097)\end{array}$ & $\begin{array}{c}8.3421 \\
(14.9276)\end{array}$ & $\begin{array}{c}0.7590 \\
(12.8487)\end{array}$ & $\begin{array}{c}4.4846 \\
(13.5546)\end{array}$ & $\begin{array}{c}7.3194 \\
(14.4576)\end{array}$ & $\begin{array}{c}-0.4643 \\
(12.1665)\end{array}$ \\
\hline German Civil Law & $\begin{array}{c}46.5509 \\
(31.1966)\end{array}$ & $\begin{array}{l}69.0136^{\mathrm{b}} \\
(32.3192)\end{array}$ & $\begin{array}{c}39.5482 \\
(30.2577)\end{array}$ & $\begin{array}{l}51.9813^{\mathrm{c}} \\
(27.6955)\end{array}$ & $\begin{array}{l}69.0419^{\mathrm{b}} \\
(31.4813)\end{array}$ & $\begin{array}{c}45.2049 \\
(28.3108)\end{array}$ & $\begin{array}{c}50.4861 \\
(30.4224)\end{array}$ & $\begin{array}{l}65.7722^{\mathrm{b}} \\
(32.4770)\end{array}$ & $\begin{array}{c}42.7064 \\
(28.5226)\end{array}$ & $\begin{array}{l}54.2743^{\mathrm{c}} \\
(27.5510)\end{array}$ & $\begin{array}{r}64.8756^{\mathrm{b}} \\
(31.3890)\end{array}$ & $\begin{array}{l}46.7182^{\mathrm{c}} \\
(26.3694)\end{array}$ \\
\hline $\begin{array}{l}\text { Scandinavian Civil } \\
\text { Law }\end{array}$ & $\begin{array}{l}-9.5145 \\
(9.5399)\end{array}$ & $\begin{array}{c}13.1235 \\
(17.1079)\end{array}$ & $\begin{array}{l}-13.2001 \\
(15.8993)\end{array}$ & $\begin{array}{c}-1.5891 \\
(14.0109)\end{array}$ & $\begin{array}{c}14.9122 \\
(17.4540)\end{array}$ & $\begin{array}{c}-5.8100 \\
(17.9810)\end{array}$ & $\begin{array}{c}0.6849 \\
(10.9855)\end{array}$ & $\begin{array}{c}12.7931 \\
(17.2217)\end{array}$ & $\begin{array}{c}-6.3229 \\
(14.5588)\end{array}$ & $\begin{array}{c}6.0348 \\
(14.2590)\end{array}$ & $\begin{array}{c}14.0401 \\
(17.6501)\end{array}$ & $\begin{array}{c}-1.2813 \\
(16.5294)\end{array}$ \\
\hline $\begin{array}{l}\text { Log of GDP Per } \\
\text { Capita }\end{array}$ & $\begin{array}{l}8.1455^{\mathrm{a}} \\
(3.0651)\end{array}$ & $\begin{array}{l}11.6735^{\mathrm{a}} \\
(4.4322)\end{array}$ & $\begin{array}{l}10.6583^{c} \\
(5.4826)\end{array}$ & $\begin{array}{c}1.4532 \\
(6.2321)\end{array}$ & $\begin{array}{c}6.7779 \\
(8.5399)\end{array}$ & $\begin{array}{c}3.4150 \\
(8.4832)\end{array}$ & $\begin{array}{c}6.9060^{\mathrm{b}} \\
(3.2951)\end{array}$ & $\begin{array}{l}10.0784^{\mathrm{a}} \\
(3.8010)\end{array}$ & $\begin{array}{l}8.5533^{c} \\
(4.5704)\end{array}$ & $\begin{array}{c}2.0926 \\
(4.0410)\end{array}$ & $\begin{array}{c}5.9574 \\
(5.9207)\end{array}$ & $\begin{array}{c}3.2755 \\
(5.5698)\end{array}$ \\
\hline $\begin{array}{l}\text { Growth of GDP Per } \\
\text { Capita }\end{array}$ & $\begin{array}{l}-2.6580 \\
(2.0693)\end{array}$ & $\begin{array}{l}-1.6114 \\
(2.3937)\end{array}$ & $\begin{array}{l}-1.9602 \\
(2.5094)\end{array}$ & $\begin{array}{l}-2.5298 \\
(1.9685)\end{array}$ & $\begin{array}{l}-1.6674 \\
(2.3665)\end{array}$ & $\begin{array}{l}-1.9188 \\
(2.3129)\end{array}$ & $\begin{array}{l}-3.0645 \\
(2.1445)\end{array}$ & $\begin{array}{l}-2.1057 \\
(2.4197)\end{array}$ & $\begin{array}{l}-2.7005 \\
(2.3573)\end{array}$ & $\begin{array}{l}-2.9550 \\
(2.1061)\end{array}$ & $\begin{array}{l}-2.2876 \\
(2.5116)\end{array}$ & $\begin{array}{l}-2.6158 \\
(2.3458)\end{array}$ \\
\hline Constant & $\begin{array}{l}-22.4006 \\
(31.8967)\end{array}$ & $\begin{array}{l}-92.6610 \\
(59.1352)\end{array}$ & $\begin{array}{l}-39.4033 \\
(49.4607)\end{array}$ & $\begin{array}{c}-6.1335 \\
(38.3266)\end{array}$ & $\begin{array}{l}-71.6429 \\
(74.0632)\end{array}$ & $\begin{array}{l}-19.9307 \\
(56.6206)\end{array}$ & $\begin{array}{l}-29.5993 \\
(39.0809)\end{array}$ & $\begin{array}{l}-78.4720 \\
(52.8018)\end{array}$ & $\begin{array}{l}-39.3088 \\
(48.6120)\end{array}$ & $\begin{array}{l}-17.4892^{\mathrm{c}} \\
(35.8571)\end{array}$ & $\begin{array}{l}-58.7005 \\
(60.9365)\end{array}$ & $\begin{array}{l}-24.7167 \\
(47.8712)\end{array}$ \\
\hline $\begin{array}{l}\text { Number of } \\
\text { Observations }\end{array}$ & 31 & 31 & 31 & 31 & 31 & 31 & 31 & 31 & 31 & 31 & 31 & 31 \\
\hline $\mathrm{R}^{2}$ & 0.36 & 0.44 & 0.35 & 0.40 & 0.45 & 0.40 & 0.41 & 0.45 & 0.42 & 0.44 & 0.46 & 0.45 \\
\hline
\end{tabular}

${ }_{46} \quad p$-value of $11.6 \%$-value of $10.9 \%$. 


\section{Table 6 - Full Regression Models}

This table presents ordinary least squares regressions for the dependent variables: ownership dispersion (columns 1 and 2); stock price synchronicity (columns 3 and 4); and stock market turnover (columns 5 and 6). The independent variables include: Public Enforcement Power*Sanction; Private Enforcement Power; anti-director rights; legal origin dummy variables; the log of GDP per capita; and the growth of GDP per capita. All variables are described in detail in Table 1. Robust standard errors are reported in parentheses. The superscripts a, b, and c denote statistical significance at the $1 \%$, $5 \%$, and $10 \%$ levels, respectively.

\begin{tabular}{|c|c|c|c|c|c|c|}
\hline & \multicolumn{2}{|c|}{$\begin{array}{l}\text { Ownership } \\
\text { Dispersion }\end{array}$} & \multicolumn{2}{|c|}{$\begin{array}{c}\text { Stock Price } \\
\text { Synchronicity }\end{array}$} & \multicolumn{2}{|c|}{$\begin{array}{c}\text { Stock Market } \\
\text { Turnover }\end{array}$} \\
\hline & (1) & (2) & (3) & (4) & (5) & (6) \\
\hline Public Enforcement Power*Sanction & $\begin{array}{c}0.0991^{\mathrm{b}} \\
(0.0443)\end{array}$ & $\begin{array}{c}0.1023^{\mathrm{b}} \\
(0.0410)\end{array}$ & $\begin{array}{l}-3.7773^{\mathrm{a}} \\
(1.1150)\end{array}$ & $\begin{array}{l}-3.9098^{\mathrm{a}} \\
(1.2280)\end{array}$ & $\begin{array}{l}35.7708^{\mathrm{a}} \\
(12.9571)\end{array}$ & $\begin{array}{r}39.3389^{\mathrm{a}} \\
(12.0731)\end{array}$ \\
\hline $\begin{array}{l}\text { Private Enforcement } \\
\text { Power }\end{array}$ & & $\begin{array}{c}-0.0029 \\
(0.0083)\end{array}$ & & $\begin{array}{c}0.1140 \\
(0.2046)\end{array}$ & & $\begin{array}{c}-2.0432 \\
(1.3847)\end{array}$ \\
\hline Accounting & $\begin{array}{c}0.0038 \\
(0.0027)\end{array}$ & $\begin{array}{c}0.0037 \\
(0.0029)\end{array}$ & $\begin{array}{c}0.1967^{\mathrm{a}} \\
(0.0596)\end{array}$ & $\begin{array}{c}0.1970^{\mathrm{a}} \\
(0.0566)\end{array}$ & $\begin{array}{c}0.8296 \\
(0.5852)\end{array}$ & $\begin{array}{c}0.8216 \\
(0.5011)\end{array}$ \\
\hline Anti-Director Rights & Yes & Yes & Yes & Yes & No & No \\
\hline Legal Origin Dummies & Yes & Yes & Yes & Yes & Yes & Yes \\
\hline Log of GDP Per Capita & Yes & Yes & Yes & Yes & Yes & Yes \\
\hline Growth of GDP Per Capita & No & No & Yes & Yes & Yes & Yes \\
\hline Constant & $\begin{array}{c}0.0480 \\
(0.3186)\end{array}$ & $\begin{array}{c}0.0412 \\
(0.3173)\end{array}$ & $\begin{array}{l}70.9056^{\mathrm{a}} \\
(3.9095)\end{array}$ & $\begin{array}{l}71.4369^{\mathrm{a}} \\
(3.9345)\end{array}$ & $\begin{array}{l}-89.0423 \\
(55.7175)\end{array}$ & $\begin{array}{l}-93.7257^{\mathrm{c}} \\
(53.5822)\end{array}$ \\
\hline Number of Observations & 29 & 29 & 28 & 28 & 29 & 29 \\
\hline $\mathrm{R}^{2}$ & 0.54 & 0.54 & 0.67 & 0.68 & 0.50 & 0.52 \\
\hline
\end{tabular}




\section{DAVIDSON INSTITUTE WORKING PAPER SERIES - Most Recent Papers}

The entire Working Paper Series may be downloaded free of charge at: www.wdi.bus.umich.edu

CURRENT AS OF 2/1/05

\begin{tabular}{|c|c|c|}
\hline Publication & Authors & Date \\
\hline $\begin{array}{l}\text { No. 746: Trade Creation and Diversion Effects of Europe’s Regional } \\
\text { Liberalization Agreements }\end{array}$ & Yener Kandogan & Feb. 2005 \\
\hline No. 745: Quality of Institutions, Credit Markets and Bankruptcy & Christa Hainz & Feb. 2005 \\
\hline $\begin{array}{l}\text { No. 744: How Transition Paths Differ: Enterprise Performance in Russia } \\
\text { and China }\end{array}$ & Sumon Bhaumik and Saul Estrin & Jan. 2005 \\
\hline $\begin{array}{l}\text { No. 743: Inflation Targeting, Between Rhetoric and Reality. The Case } \\
\text { of Transition Economies }\end{array}$ & Daniel Daianu and Laurian Lungu & Jan. 2005 \\
\hline $\begin{array}{l}\text { No. 742: How Does Law Affect Finance? An Empirical Examination of } \\
\text { Tunneling in an Emerging Market }\end{array}$ & $\begin{array}{l}\text { Vladimir Atanasov, Conrad S. } \\
\text { Ciccotello, \& Stanley B. Gyoshev }\end{array}$ & Jan. 2005 \\
\hline $\begin{array}{l}\text { No. 741: Do Insider Trading Laws Matter? Some Preliminary } \\
\text { Comparative Evidence }\end{array}$ & Laura Nyantung Beny & Jan. 2005 \\
\hline $\begin{array}{l}\text { No. 740: Autopsy on an Empire: Understanding Mortality in Russia and } \\
\text { the Former Soviet Union }\end{array}$ & $\begin{array}{l}\text { Elizabeth Brainerd and David M. } \\
\text { Cutler }\end{array}$ & Jan. 2005 \\
\hline $\begin{array}{l}\text { No. 739: Not Separate, Not Equal: Poverty and Inequality in Post- } \\
\text { Apartheid South Africa }\end{array}$ & $\begin{array}{l}\text { Johannes G. Hoogeveen and Berk } \\
\text { Özler }\end{array}$ & Jan. 2005 \\
\hline $\begin{array}{l}\text { No. 738: The Marketing Structure in Agribusiness during the Transition } \\
\text { in Bulgaria }\end{array}$ & $\begin{array}{l}\text { Steve Murray, Yordan Staykov, } \\
\text { and Valentin Katzerov }\end{array}$ & Jan. 2005 \\
\hline No. 737: Passive Creditors & $\begin{array}{l}\text { Koen Schoors and Konstantin } \\
\text { Sonin }\end{array}$ & Jan. 2005 \\
\hline $\begin{array}{l}\text { No. 736: From a currency board to the euro: Public attitudes toward } \\
\text { unilateral euroization in Bulgaria }\end{array}$ & Neven T. Valev & Jan. 2005 \\
\hline No. 735: Dictators and Their Viziers: Agency Problems in Dictatorships & $\begin{array}{l}\text { Georgy Egorov and Konstantin } \\
\text { Sonin }\end{array}$ & Jan. 2005 \\
\hline $\begin{array}{l}\text { No. 734: Foreign Investment, Corporate Ownership, and Development: } \\
\text { Are Firms in Emerging Markets Catching Up to the World Standard? }\end{array}$ & $\begin{array}{l}\text { Klara Sabirianova, Jan Svejnar, } \\
\text { and Katherine Terrell }\end{array}$ & Jan. 2005 \\
\hline $\begin{array}{l}\text { No. 733: Businessman Candidates: Special-Interest Politics in Weakly } \\
\text { Institutionalized Environments }\end{array}$ & $\begin{array}{l}\text { Scott Gehlbach and Konstantin } \\
\text { Sonin }\end{array}$ & Dec. 2004 \\
\hline $\begin{array}{l}\text { No. 732: Measuring the Institutional Change of the Monetary Regime } \\
\text { in a Political Economy Perspective }\end{array}$ & $\begin{array}{l}\text { Nikolay Nenovsky and Yorgos } \\
\text { Rizopoulos }\end{array}$ & Dec. 2004 \\
\hline $\begin{array}{l}\text { No. 731: Impact of Regulated Price Adjustments on Price Variability in } \\
\text { a Very Low Inflation Transition Economy: Case of Armenia }\end{array}$ & Aghassi Mkrtchyan & Nov. 2004 \\
\hline $\begin{array}{l}\text { No. 730: Reform, FDI and Economic Growth: Tale of the Tortoise and } \\
\text { the Hare }\end{array}$ & $\begin{array}{l}\text { Bruno Merlevede and Koen } \\
\text { Schoors }\end{array}$ & Nov. 2004 \\
\hline $\begin{array}{l}\text { No. 729: The Effects of Transition and Political Instability On Foreign } \\
\text { Direct Investment Inflows: Central Europe and the Balkans }\end{array}$ & $\begin{array}{l}\text { Josef C. Brada, Ali M. Kutan, } \\
\text { and Taner M. Yigit }\end{array}$ & Nov. 2004 \\
\hline $\begin{array}{l}\text { No. 728: Institutional Distance and International Business Strategies } \\
\text { in Emerging Economies }\end{array}$ & $\begin{array}{l}\text { Delia Ionascu, Klaus E. Meyer, } \\
\text { and Saul Erstin }\end{array}$ & Nov. 2004 \\
\hline No. 727: Explaining Patterns of Corruption in the Russian Regions & $\begin{array}{l}\text { Phyllis Dininio and Robert W. } \\
\text { Orttung }\end{array}$ & Nov. 2004 \\
\hline $\begin{array}{l}\text { No. 726: The Politics of Institutional Learning and Creation: Bank } \\
\text { Crises and Supervision in East Central Europe }\end{array}$ & Gerald A. McDermott & Nov. 2004 \\
\hline $\begin{array}{l}\text { No. 725: International Business and Development Economics: A } \\
\text { Winning Combination }\end{array}$ & Tamir Agmon & Nov. 2004 \\
\hline $\begin{array}{l}\text { No. 724: Importing High-Risk Capital and Revealing Hidden } \\
\text { Comparative Advantages }\end{array}$ & Tamir Agmon & Oct. 2004 \\
\hline $\begin{array}{l}\text { No. 723: Which entrepreneurs expect to expand their businesses? } \\
\text { Evidence from survey data in Lithuania }\end{array}$ & $\begin{array}{l}\text { Ruta Aidis and Tomasz } \\
\text { Mickiewicz }\end{array}$ & Oct. 2004 \\
\hline No. 722: Russia from Bust to Boom: Oil, Politics or the Ruble? & $\begin{array}{l}\text { Bruno Merlevede and Koen } \\
\text { Schoors }\end{array}$ & Oct. 2004 \\
\hline No. 721: Distance to the Efficiency Frontier and FDI Spillovers & $\begin{array}{l}\text { Klara Sabirianova Peter, Jan } \\
\text { Svejnar, and Katherine Terrell }\end{array}$ & Sept. 2004 \\
\hline $\begin{array}{l}\text { No. 720: An Analysis of Gender Wage Differentials in Russia from } \\
\text { 1996-2002 }\end{array}$ & Rita Hansberry & Sept. 2004 \\
\hline
\end{tabular}

